\title{
Impact of IoT on Manufacturing Industry 4.0: A New Triangular Systematic Review
}

\author{
Tahera Kalsoom ${ }^{1}\left(\mathbb{D}\right.$, Shehzad Ahmed ${ }^{2, *} \mathbb{*}$, Piyya Muhammad Rafi-ul-Shan ${ }^{3}$, Muhammad Azmat ${ }^{4}{ }^{\oplus}$, \\ Pervaiz Akhtar $\left.{ }^{5}{ }^{(}\right)$, Zeeshan Pervez ${ }^{1}\left(\mathbb{D}\right.$, Muhammad Ali Imran ${ }^{6}\left(\mathbb{D}\right.$ and Masood Ur-Rehman ${ }^{6}(\mathbb{D})$ \\ 1 School of Computing, Engineering \& Physical Sciences, University of the West of Scotland, \\ Paisley PA1 2BE, UK; tahera.kalsoom@uws.ac.uk (T.K.); zeeshan.pervez@uws.ac.uk (Z.P.) \\ 2 School of Business \& Creative Industries, University of the West of Scotland, Paisley PA1 2BE, UK \\ 3 Cardiff School of Management, Cardiff Metropolitan University, Cardiff CF5 2YB, UK; PRafi-Ul-Shan@cardiffmet.ac.uk \\ 4 Department of Engineering Systems \& Supply Chain Management (ESSCM), College of Engineering and \\ Physical Sciences, Aston University, Birmingham B4 7ET, UK; m.azmat@aston.ac.uk \\ 5 Business School, University of Aberdeen, Aberdeen AB24 5UA, UK; pervaiz.akhtar@abdn.ac.uk \\ 6 James Watt School of Engineering, University of Glasgow, Glasgow G12 8QQ, UK; \\ muhammad.imran@glasgow.ac.uk (M.A.I.); masood.urrehman@glasgow.ac.uk (M.U.-R.) \\ * Correspondence: shehzad.ahmed@uws.ac.uk
}

Citation: Kalsoom, T.; Ahmed, S.; Rafi-ul-Shan, P.M.; Azmat, M.; Akhtar, P.; Pervez, Z.; Imran, M.A.;

Ur-Rehman, M. Impact of IoT on Manufacturing Industry 4.0: A New Triangular Systematic Review. Sustainability 2021, 13, 12506. https:/ / doi.org/ 10.3390/su132212506

Academic Editor: Ashutosh Tiwari

Received: 30 September 2021

Accepted: 5 November 2021

Published: 12 November 2021

Publisher's Note: MDPI stays neutral with regard to jurisdictional claims in published maps and institutional affiliations.

Copyright: (c) 2021 by the authors. Licensee MDPI, Basel, Switzerland. This article is an open access article distributed under the terms and conditions of the Creative Commons Attribution (CC BY) license (https:/ / creativecommons.org/licenses/by/ $4.0 /)$.

\begin{abstract}
The Internet of Things (IoT) has realised the fourth industrial revolution concept; however its applications in the manufacturing industry are relatively sparse and primarily investigated without contextual peculiarities. Our research undertakes an intricate critical review to investigate significant aspects of IoT applications in the manufacturing Industry 4.0 perspective to address this gap. We adopt a systematic literature review approach by Denyer and Tranfield (2009) to carry out critical analyses that help develop future research domains based on empirical studies. We describe key knowledge gaps in the existing literature and empirical studies by exploring the main contribution categories and finding six critical differences between traditional and manufacturing Industry 4.0 and 10 enablers and 11 challenges of IoT applications. Finally, an agenda for future research is proposed with 11 research domains to focus on the recognised gaps.
\end{abstract}

Keywords: IoT; systematic review; Industry 4.0; smart factory; drivers and challenges of IoT

\section{Introduction}

The Internet of Things (IoT) connects the physical and digital worlds to improve services, for example, easing traffic congestion, enhancing healthcare and improving the speed of customer service by faster communication and better analytics [1,2]. The manufacturing industry embracing emerging technologies such as wireless sensors, cloud computing, embedded systems, and big data has given rise to a fourth industrial revolution called Industry 4.0 [3]. This industrial revolution has enabled a technologically enhanced globalised world where advanced technologies can directly control the manufacturing industry's machines, services, factories and infrastructure [4] and influence intelligent procedural and strategic decisions [5]. Globalisation, changing customer demands and evolutions in information and communication technology (ICT) are acknowledged as the key drivers [6], causing reforms in service industries and manufacturing operational strategies $[1,7,8]$. Consequently, it enables various industries to be more efficient and flexible, increasing productivity and yield [7]. Similarly, manufacturing companies must continuously develop their production systems and adapt to fluctuating market demands, customer requirements and supply conditions to remain competitive in a globalised environment [8,9]. Thus, it significantly impacts the market and manufacturing industry while affecting the products whole life cycles.

The empirical research reported that many firms had not identified the complex characteristics of Industry 4.0, therefore having uncertainties regarding what it represents 
for them [10-12]. Some researchers [13-16] state the perks of IoT in the manufacturing industry, including enhanced proficiency, increased energy and transport efficiency and greater control and auditing in manufacturing and supply processes, with the likeliness of a great increase in value to industry and global economy. Technological advancements and innovations in business models impact the manufacturing industry's firm performance and long-term sustainability $[17,18]$. Therefore, manufacturers need to adopt IoT [19-22] to remain competitive in a hypercompetitive market. However, others $[19,23,24]$ are concerned about IoT adoption and associated security and privacy risks for businesses and customers. Several studies have been conducted to assess the impact of IoT on various areas such as sustainability, product development, organisational structure, strategic management and lean manufacturing $[20,21]$. Most of this investigation emphasises the IoT influences and threats associated with connectivity, tracking, flexibility, transparency, information sharing and traceability within Industry 4.0 [17]. Though widespread research has been done covering these domains, it was revealed that investigation on the impact of IoT on the manufacturing industry in Industry 4.0 is minimal.

Furthermore, an important yet underexplored problem is the valuation and measurement of IoT impact on manufacturing; this requires consideration from theoretical and practical perspectives [22,25-27]. To address these critical knowledge gaps, this research adopts the robust and organised methodology proposed by [28] by carrying out a systematic review of the IoT literature. This paper intends to conduct a systematic review, presenting a comprehensive analysis of the impact of IoT on manufacturing Industry 4.0 in the peer-reviewed literature. Our contribution here is to synthesise the inconsistent and disintegrated literature, develop a contextual framework and recognise knowledge gaps for future research that will help enhance the knowledge of the phenomenon in Industry 4.0.

The above discussion reveals that various authors have conducted literature reviews on IoT and Industry 4.0 at multiple stages over the last ten years. However, there is a paucity in thoroughness and rigour within narrative literature reviews [29]. On the other hand, evidence-based reviews provide a thorough and transparent result as they give numerous viewpoints to the literature. An example of an evidence-based literature survey is the systematic review approach [29,30]. This paper follows the SLR approach adopted by [28]. Section 2 of this paper presents Industry 4.0, followed by the methodology used in this systematic literature review. This will also include details about the article selection process following inclusion/exclusion criteria and analysis of the selected literature. Section 3 highlights key findings and potential implications. Finally, this paper concludes with the key findings, suggestions for managers and paths for further research investigation.

\section{Industry 4.0}

The term "Industry 4.0", devised in 2011, in Germany, to label the strategic industrial policies within the country, endorsed the computerisation of manufacturing [31]. The German government instantly recognised the potential of Industry 4.0, which is also being adopted now at a global level, representing autonomous manufacturing processes through devices and machines that converse with each other through digital interconnectivity $[32,33]$. Even though some of the Industry 4.0 technologies (such as IoT) are already in practice, Industry 4.0 has served as the future of manufacturing and has been an active research domain for almost an era.

Implementation of IoT has enabled the manufacturers to embrace digital transformations from multiple contexts such as customer focus, efficient productivity, automation, competitive advantages and speedy returns $[1,34,35]$. High-speed and low-cost electronic circuits, swift signal processing methods and innovative advances in manufacturing technologies have marked the rapid evolution in industrial processes [36,37]. Similarly, the number of sensor systems used and the diversity of their applications are increasing continuously. These technologically enhanced sensors and devices can converse and collaborate via the internet and perform remote monitoring and control $[28,38]$. The characteristic requirements of IoT devices, such as small dimensions and narrow bandwidth, show the 
distinct properties that the sensors must possess, the most important of which is miniaturisation $[33,39]$. The vast adoption of computer numerical control (CNC) and industrial automatons has facilitated resilience in manufacturing systems [34,35,40]. In contrast, computer-aided design (CAD) and computer-aided process planning (CAPP) have resulted in computer-integrated helpful manufacturing [24,41]. Such machine-to-machine (M2M) or human-machine interactions generate vast amounts of data that businesses can utilise for effective performance [42-44].

Such a huge volume of data comes with the responsibility of analysing and utilising it so that IoT networks can operate accurately [45]. The networks create unnecessary data, so organisations use analytics tools vital for the business [46]. Industry 4.0, originator of smart factories [47-50], allows the use of innumerable radical technologies that include cloud computing, big data analytics, artificial intelligence, 3D printing and advanced robotics [51]. Big data analytics transform gathered data into actionable data that can optimise processes and play a critical role in many manufacturing operations, such as predictive maintenance and asset management $[36,52]$. WSANs can operate in environments that enable them to perform more complex activities by executing self-awareness and self-configuration mechanisms $[42,53]$. Many manufacturers use IoT-based predictive maintenance to monitor the health of spindles to avoid breaking and extensive repairs [54,55]. For example, damage can be predicted by adopting an IoT-based predictive maintenance solution that will collect data from multiple sensors attached to machines and analyse the collected data, therefore helping to identify fragile parts before they break $[2,56]$. Factories become highly receptive and prognostic by learning and modifying from real-time information that helps to elude downtime and other likely disasters in the operational processes. Such intelligent factories are known as smart factories $[47,57]$. With IoT, the factories can develop actionable insight over the data generated from production processes, maintenance schedules and surrounding environments [58].

\section{Research Methodology and Data Characteristics}

The systematic literature review (SLR) method was followed to find and analyse IoT and Industry 4.0 literature. SLR is an evidence-based methodology that helps classify, select and investigate the pertinent data to deliver in-depth knowledge of information already acknowledged and prospective gaps for future research [30]. Its fundamental principles of transparency and inclusivity enable researchers to have an objective overview of the findings and lessen bias and error issues [30,59]. We used a five-phase process in our SLR method. Figure 1 presents the steps in this SLR on the impact of IoT on manufacturing Industry 4.0.

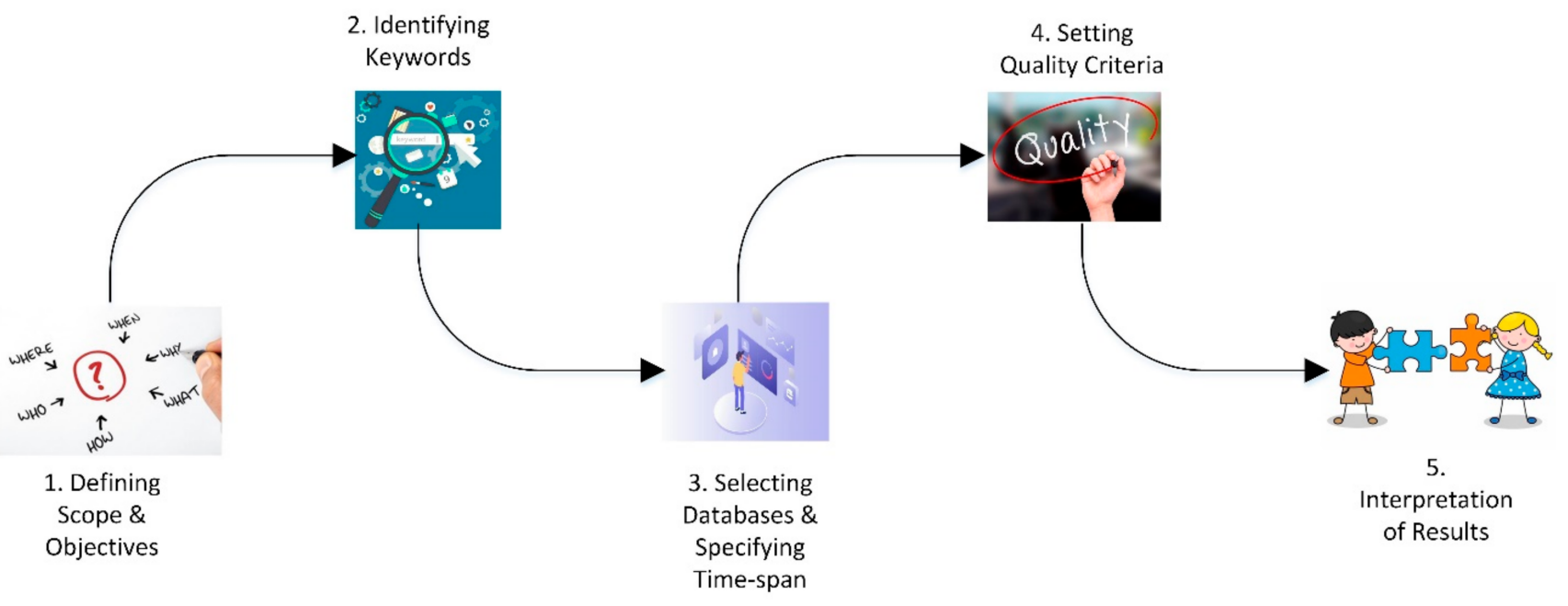

Figure 1. Systematic literature review steps.

The first phase of an SLR involves determining the scope of the research along with the aims. The main objectives of this SLR are twofold: firstly, identifying critical changes in 
traditional manufacturing systems because of Industry 4.0; secondly, recognising the key drivers and challenges of IoT in the context of the manufacturing industry. The primary domain of our research is the use of IoT in the manufacturing industry and its drivers and barriers.

The second phase involved finding the keywords concerning the objectives and research domains to position this study suitably. Twenty-three keywords were identified after conducting comprehensive multifold brainstorming sessions amongst the authors. Using Boolean logic, the keywords were fixed by combining them into a series of search strings to enhance creditability, for instance, "IoT AND/OR Manufacturing Industry", "Industry 4.0 AND/OR IoT" and "IoT AND/OR Manufacturing AND/OR Industry 4.0". Nine relevant search strings were identified using TITLE-ABS-KEY, Limit-to-LanguageENGLISH and finalised after continuous refining, which was used to search secondary data (Table 1).

Table 1. Keywords and search strings.

\begin{tabular}{|c|c|c|c|c|c|c|}
\hline ID & Query & WoS & EI & SD & Wiley & Taylor \& Francis \\
\hline 1 & IoT AND Industry $4.0 *$ & 56 & 49 & 23 & 20 & 4 \\
\hline 2 & manufacturing AND industry AND Industry 4.0 * & 45 & 39 & 14 & 25 & 9 \\
\hline 3 & manufacturing AND industry AND IoT * & 34 & 39 & 14 & 17 & 7 \\
\hline 4 & manufacturing AND industry AND $4.0^{*}$ & 28 & 27 & 5 & 10 & 7 \\
\hline 5 & manufacturing AND industry AND digital * & 16 & 15 & 5 & 2 & 0 \\
\hline 6 & $\begin{array}{c}\text { drivers AND Industry 4.0 AND manufacturing } \\
\text { AND industry * }\end{array}$ & 10 & 10 & 13 & 8 & 1 \\
\hline 7 & $\begin{array}{l}\text { opportunities AND Industry 4.0 AND } \\
\text { manufacturing AND industry* }\end{array}$ & 10 & 6 & 6 & 1 & 3 \\
\hline 8 & $\begin{array}{l}\text { challenges AND Industry 4.0 AND manufacturing } \\
\text { AND industry * }\end{array}$ & 6 & 5 & 7 & 0 & 4 \\
\hline 9 & $\begin{array}{l}\text { barriers AND Industry 4.0 AND manufacturing } \\
\text { AND industry * }\end{array}$ & 8 & 2 & 1 & 1 & 0 \\
\hline Total & & 213 & 192 & 88 & 84 & 35 \\
\hline
\end{tabular}

* TITLE-ABS-KEY; Limit-to-Language-ENGLISH.

The third phase included selecting the most significant databases and stipulating the time span for the publications. We used five academic databases, Emerald Insight, Taylor and Francis, ScienceDirect, Wiley and Web of Science. These databases provided full-length abstracts within peer-reviewed, high-quality journal articles [59], thus enabling us to find high-quality papers that are easy to manage and analyse. Our initial analysis of these databases suggested that publication numbers on IoT applications and the use of IoT have seen an increased interest of academics and practitioners alike since $2005[12,25,26,60]$. Therefore, the time span of our research was specified for 11 years, 2009 to 2020, which saw significant interest in research on IoT and Industry 4.0.

The fourth phase was concerned with ensuring the quality of our search process. A robust search process was carried out to ensure data validity and reliability. For example, we followed the inclusion/exclusion criterion provided by [61] for our data search and to shortlist and finalise papers for this research:

- Empirical journal articles in the discipline of business management.

- Multidisciplinary empirical journal articles on IoT and Industry 4.0.

- Papers from peer-reviewed journals in English.

- Industry magazine papers, white papers and personal blogs were disqualified.

- Papers with at least one keyword in the title or abstract were selected to ensure relevance.

- To be sure of the empirical relevance, all the articles were read completely.

- Duplicates and out of specified period papers were excluded. 
We also applied quality attributes (QAs), a sequence of checklist questions and finalised our papers for analysis. QA questions were as follows: Does the selected paper discuss any IoT applications (QA1)? Does the selected paper relate to Industry 4.0 (QA2)? Does it discuss the drivers and challenges of IoT applications (QA3)? Does the selected paper have findings or results that are relevant to our research domain (QA4)? All the authors were engaged in this process to crosscheck the quality attributes in our finalised papers. This robust process helped us remove any possible subjective biases, ensuring the validity and reliability of our selection process and enhancing the overall quality of our finalised papers.

Using keywords that we designed based on brainstorming sessions, our initial electronic search enabled us to find 612 papers from five databases. The refined keywords, using Boolean logic, further reduced papers to 503. This was followed by applying inclusion/exclusion criteria (as mentioned in phase 4 of SLR) and quality attributes (above), resulting in 108 final papers for this review. Finally, we ensured empirical relevance by reading finalised papers in their entirety. Figure 2 highlights our search process and quality criteria to determine the most important papers for this research. The yearly publication numbers of our finalised papers are shown in Figure 3. IoT and I4.0 have grabbed the attention of academics since 2005, with a consistent increase in publications in later years. It is revealed that most of the research on IoT-related concepts was carried out in 2016, whereas 2019 saw a hike in I4.0 publications. This shows that academics have recently found interest in analysing the domains surrounding IoT and I4.0.

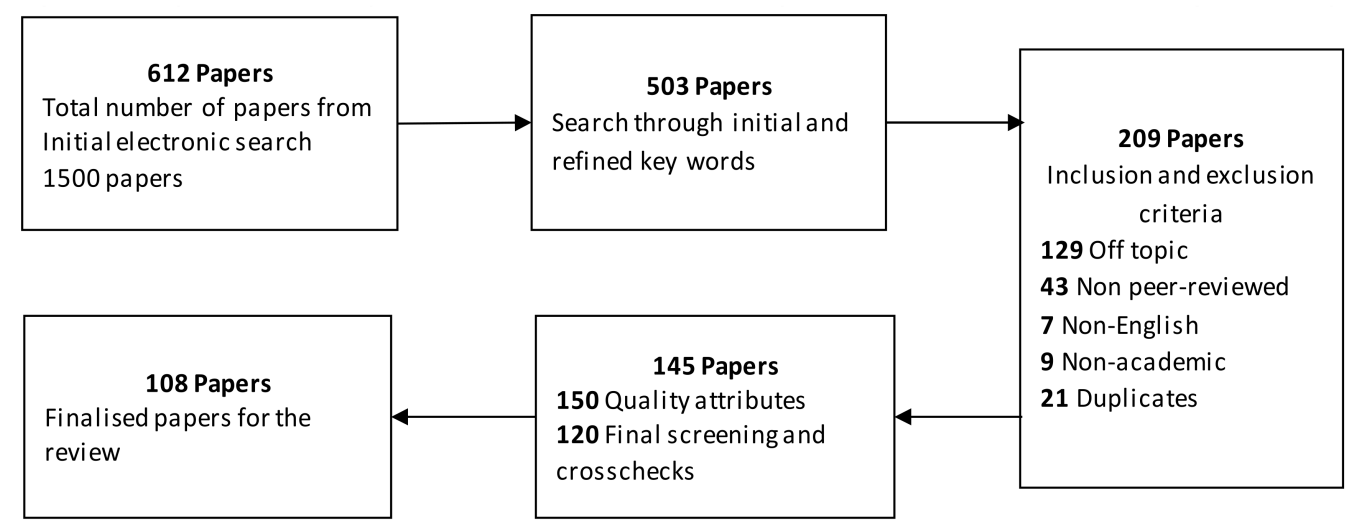

Figure 2. Shortlisting papers based upon inclusion and exclusion criteria and quality attributes.

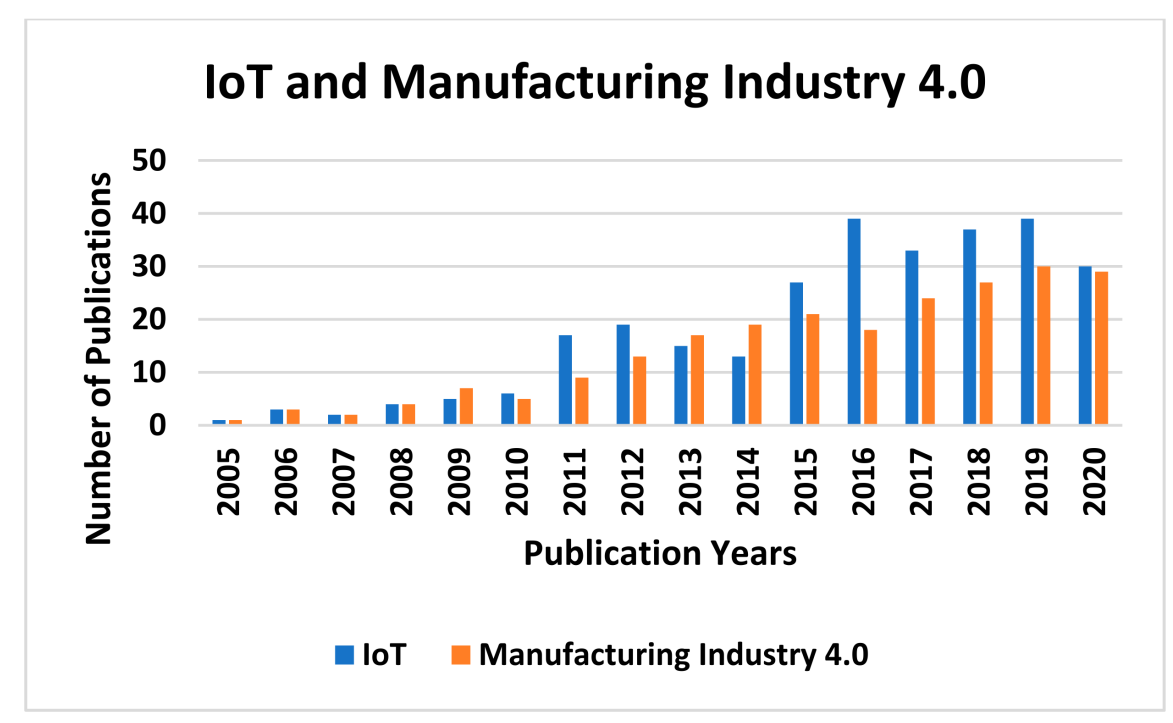

Figure 3. Yearly number of published papers on IoT and manufacturing Industry 4.0. 
With the help of VOSviewer, which aids researchers in producing, envisioning and discovering maps based on network data, a network map of country coauthorship was created (Figure 4). In Figure 4, clusters are formed by the frequency of occurrence. In contrast, the circle's dimension indicates the number of publications, with the thickness of the line representing collaboration size. It has been revealed that two clusters formed of eight countries contribute to the most extensive set of connections by collaborating in more than five publications. In addition, China showed the most substantial collaboration with other countries, including the United States and the United Kingdom, followed by the United Kingdom, the United States and India. Moreover, Figure 4 reveals that the most recent collaborations were done in Italy, Brazil and India. Using VOSviewer, a network visualisation of keyword co-occurrence was created (Figure 5). Based on the criteria that a keyword should appear in a minimum of five papers to be analysed, it was revealed that 100 out of 108 papers fit into the criteria. Therefore, the analysis generated nine clusters with 800 links and a total link strength of 323.

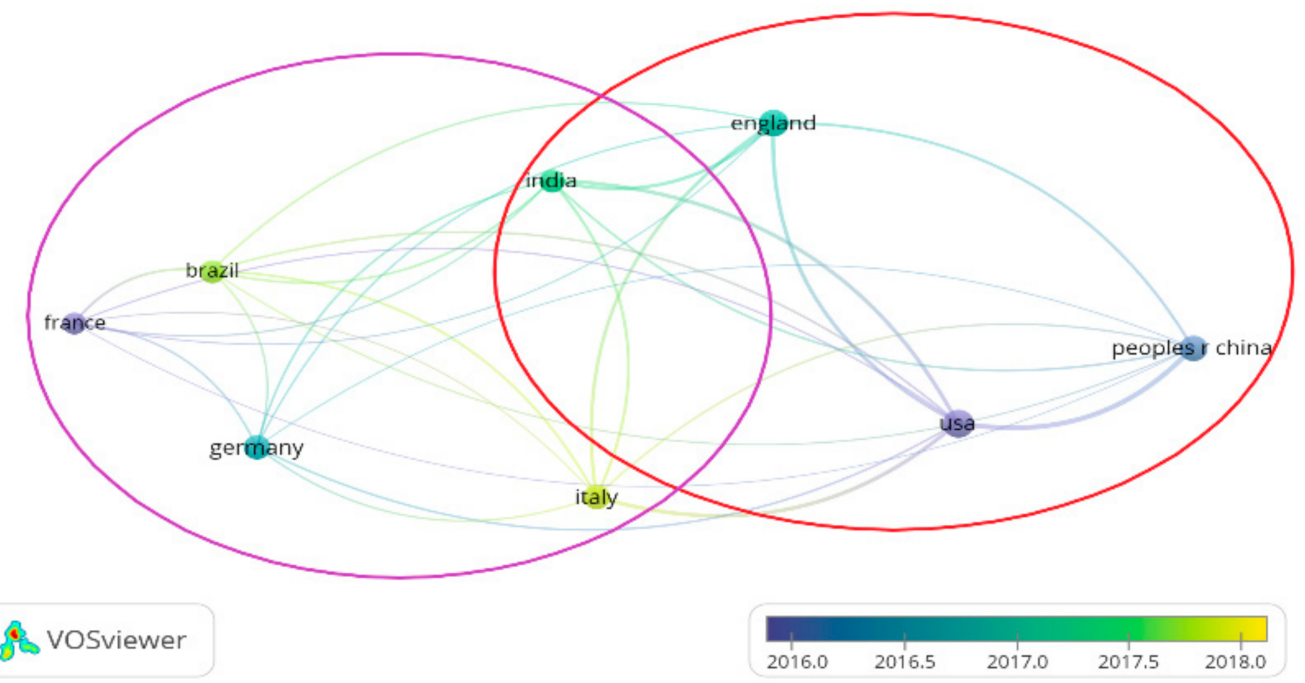

Figure 4. Network visualisation map of country coauthorship.

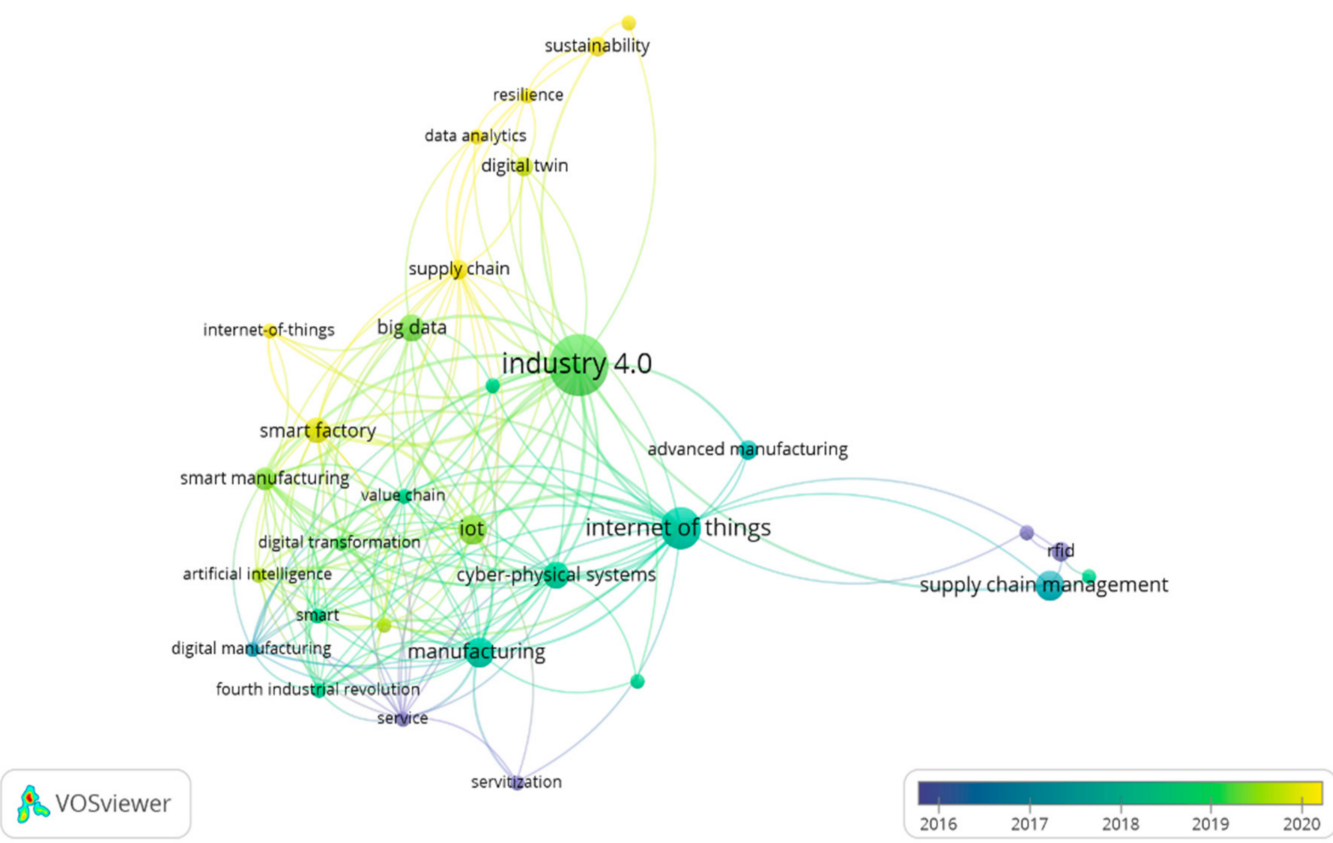

Figure 5. Keyword network visualisation map based on co-occurrence. 
Furthermore, it was found that Industry 4.0 had the highest word frequency due to the most substantial link strength with other words such as IoT, supply chain management, smart factory and manufacturing. In addition, the most recent studies focused on keywords such as smart factory, digital twin, IoT, supply chain and sustainability. This indicates a rapid growth in studies conducted using the keywords mentioned above.

The selected studies were based on several domains related to IoT and its applications in the manufacturing Industry 4.0. These domains were informed by our research objectives, inclusion and exclusion criteria and quality attributes. Many publications were found in IoT applications, followed by Industry 4.0 and IoT challenges, IoT drivers and interaction between humans and machines (Figure 6). Our finalised papers presented us with two unique features. First, Figure 6 represents the most critical domains in the extant empirical research, focused on by the developed or technically developed countries in their investigations. Second, the most prominent methods of study were reviews and conceptual framework developments. This could be attributed to the newness of the discipline and the conceptual understanding of multiple issues in the domain [62]. Figure 7 shows investigation methods applied in our finalised papers. Table 2 shows general information about the key papers in our research domain.

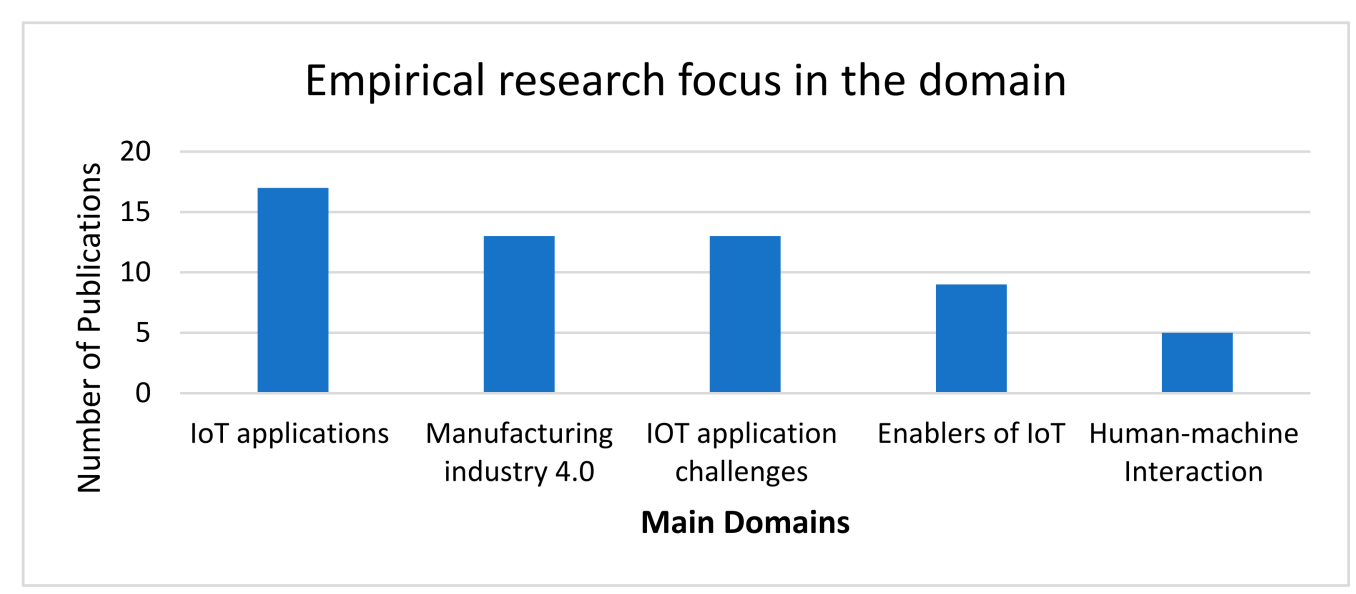

Figure 6. Important domains in the extant research.

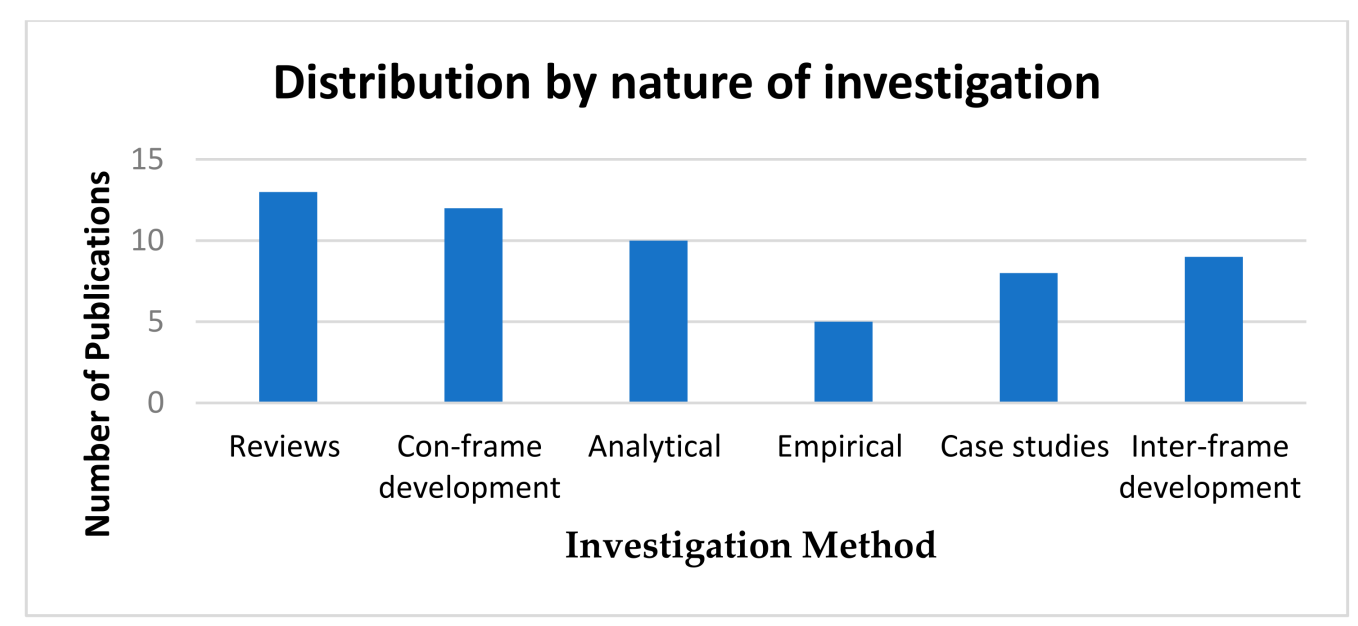

Figure 7. Distribution by nature of investigation. 
Table 2. Key papers in our research domain.

\begin{tabular}{|c|c|c|c|c|c|}
\hline Title & Authors & Year & Journal & $\begin{array}{l}\text { Type of } \\
\text { Study }\end{array}$ & Geo. Area \\
\hline $\begin{array}{c}\text { "Internet of things and supply chain management: } \\
\text { A literature review" }\end{array}$ & {$[63]$} & 2019 & $I J P R$ & Review & UAE \\
\hline $\begin{array}{c}\text { "A review of Industry } 4.0 \text { in supply chain } \\
\text { management studies" }\end{array}$ & [25] & 2019 & JMTM & Review & India \\
\hline $\begin{array}{c}\text { "Industry } 4.0 \text { technologies: Implementation patterns in } \\
\text { manufacturing companies" }\end{array}$ & {$[64]$} & 2019 & IJPE & $\begin{array}{l}\text { Empirical } \\
\text { (Survey } \\
n=92)\end{array}$ & Brazil \\
\hline $\begin{array}{c}\text { "Barriers to the adoption of Industry } 4.0 \text { technologies in } \\
\text { the manufacturing sector" }\end{array}$ & [65] & 2019 & IJPE & Review & India \\
\hline $\begin{array}{c}\text { "The advantages of Industry } 4.0 \text { applications for } \\
\text { sustainability: Results from a sample of } \\
\text { manufacturing companies" }\end{array}$ & [2] & 2020 & $\begin{array}{l}\text { Sustainability } \\
\text { (MDPI) }\end{array}$ & $\begin{array}{l}\text { Empirical } \\
\text { (Survey } \\
n=65)\end{array}$ & Italy \\
\hline "The evolution and future of manufacturing: A review" & {$[66]$} & 2016 & JMS & Review & Canada \\
\hline $\begin{array}{l}\text { "Industry } 4.0 \text { and the current status as well as } \\
\text { prospects on logistics" }\end{array}$ & [67] & 2017 & $C I$ & Review & Switzerland \\
\hline $\begin{array}{l}\text { "Past, present and future of Industry } 4.0 \text {-A systematic } \\
\text { literature review and research agenda proposal" }\end{array}$ & [15] & 2017 & $I J P R$ & Review & China \\
\hline $\begin{array}{l}\text { "Industry 4.0: A survey on technologies, applications } \\
\text { and open research issues" }\end{array}$ & [16] & 2017 & JIII & Review & China \\
\hline $\begin{array}{l}\text { "A review of the internet of things embedded } \\
\text { sustainable supply chain for Industry } 4.0 \text { requirements" }\end{array}$ & [20] & 2019 & CIE & Review & India \\
\hline $\begin{array}{c}\text { "The industrial internet of things (IoT): } \\
\text { An analysis framework" }\end{array}$ & [68] & 2018 & $C I$ & Review & UK \\
\hline $\begin{array}{l}\text { "Digital Supply Chain: Literature review and a } \\
\text { proposed framework for future research" }\end{array}$ & [60] & 2018 & $C I$ & Review & Turkey \\
\hline $\begin{array}{l}\text { "A critical investigation of Industry } 4.0 \text { in } \\
\text { manufacturing: theoretical operationalisation } \\
\text { framework" }\end{array}$ & [47] & 2018 & $P P C$ & Review & UAE \\
\hline $\begin{array}{l}\text { "Literature review of Industry } 4.0 \text { and } \\
\text { related technologies" }\end{array}$ & [61] & 2020 & JIM & Review & Turkey \\
\hline $\begin{array}{l}\text { "The expected contribution of Industry } 4.0 \text { technologies } \\
\text { for industrial performance" }\end{array}$ & [69] & 2018 & $I J P E$ & $\begin{array}{l}\text { Empirical } \\
\text { (Survey } \\
n=2225)\end{array}$ & Brazil \\
\hline
\end{tabular}

The coauthorship network analysis revealed that the collaboration among the researchers was scattered and dispersed, forming 15 clusters (Figure 8). In addition, the disconnected clusters indicated that the research collaboration within the context of IoT and I4.0 is not well established. This specifies the need to have well-established and collaborative research within the topic under study. It was also found that recent studies within this domain are limited, which is indicated by small-sized clusters. 


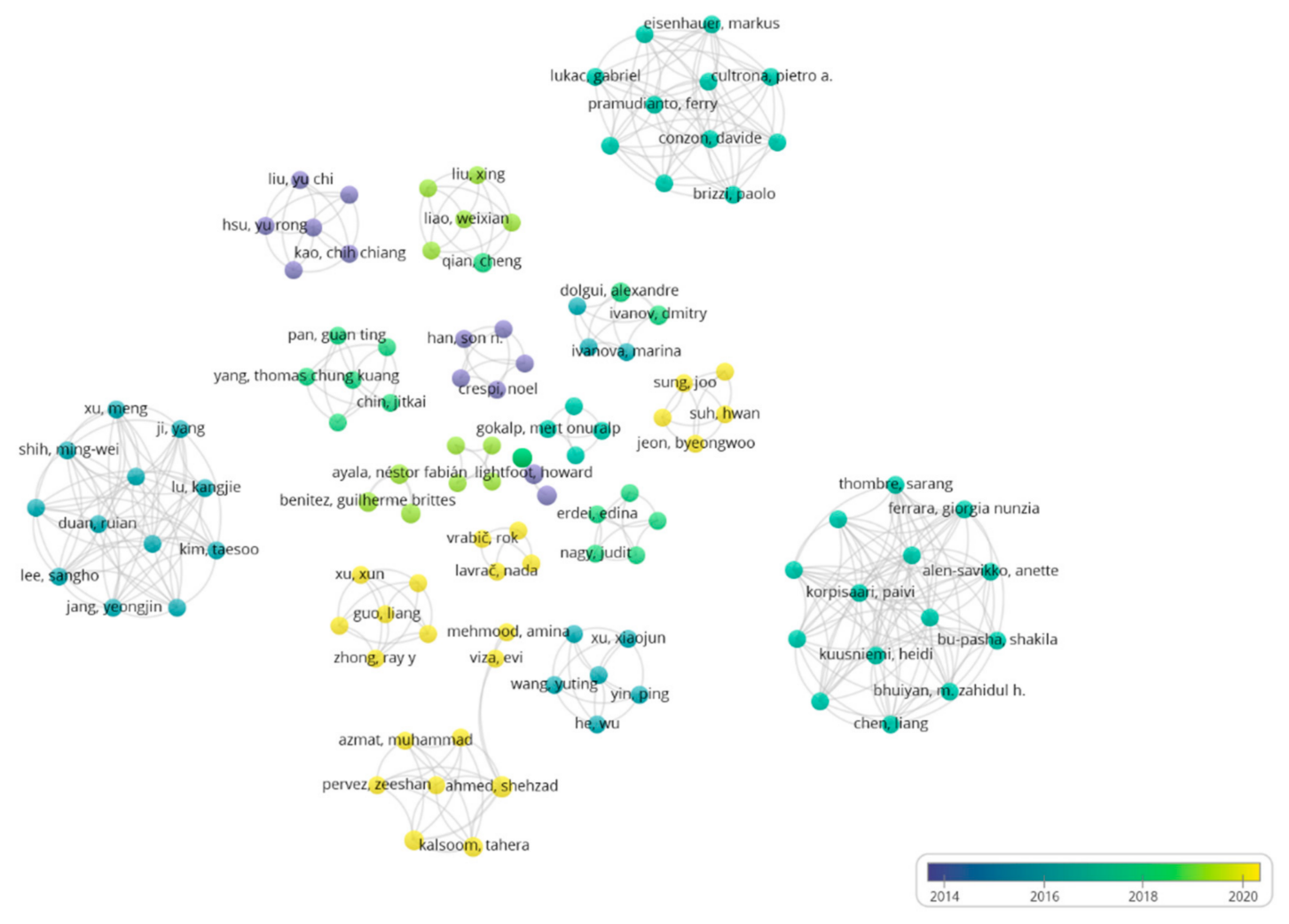

Figure 8. Network visualisation depicting coauthorship.

\section{Findings}

\subsection{Conceptualisation of IoT in I4.0}

With the rapid growth in miniature embedded systems and the increasing significance of pervasive computing, the next-generation industrial ecosystems have come to rise with the ability to adopt low-power interconnected devices for control and monitoring functions [66,70]. Modern electronics and wireless data communication systems leverage these systems [71-73]. The complexity of manufacturing systems allows numerous IoT applications in these processes $[11,15]$. The empirical research has reported three main areas of IoT application. First, in manufacturing operations, several elements are included: monitoring, human-machine interaction, asset management, planning, performance optimisation, intelligent manufacturing and end-to-end transparency in operations $[18,74,75]$. Second, in production asset management and maintenance, elements such as production resource tracking and monitoring - from the site of the assets to the checking of parameters such as quality, efficiency and possible damage or failures-make up the maintenance and production resource management in manufacturing industries [53,76-78]. Third, field service includes installing, repairing and maintaining industrial equipment $[76,79]$.

Rapidly changing digital technologies are, both in scope and magnitude, shifting the world towards more connected processes, consequently influencing the business management approaches [80]. Advanced real-time ICT skills allow information to be easily accessible across various industries, thus decreasing lead times and increasing responsiveness [81]. With IoT, factories can communicate production processes, maintenance schedules and surrounding environments [61,82]. The adaption of IoT makes the manufacturing process increasingly intelligent and dynamic, creating an environment where automation and self-optimisation can aid the machinery and equipment to enhance manufacturing processes [62]. Powered by connectivity and sensors, IoT helps the factories generate useable, real-time data insights related to the physical things in both the factory and the supply chain. When combined with data analytics, new technologies and faster networks, these data enable the manufacturers to maintain their assets better and boost 
production efficiency [61]. IoT allows manufacturers to enhance efficiency and productivity and produce tremendous data to facilitate procedural and strategic decision-making, thus giving rise to smart factories [83]. Table 3 provides key elements of IoT for a better conceptual understanding of it.

Table 3. Key elements of IoT.

\begin{tabular}{|c|c|c|c|c|c|c|c|c|c|}
\hline $\begin{array}{l}\text { IoT and I4.0 } \\
\text { References }\end{array}$ & Agility & Visibility & $\begin{array}{l}\text { Tracking and } \\
\text { Information } \\
\text { Sharing }\end{array}$ & $\begin{array}{l}\text { Control and } \\
\text { Coordination } \\
\text { of Processes }\end{array}$ & $\begin{array}{c}\text { Use of } \\
\text { Intelligent } \\
\text { Interfaces }\end{array}$ & $\begin{array}{l}\text { Sensing and } \\
\text { Actuating } \\
\text { Abilities }\end{array}$ & $\begin{array}{c}\text { Self- } \\
\text { Configuring }\end{array}$ & $\begin{array}{c}\text { Interoperable } \\
\text { Communication } \\
\text { Protocols }\end{array}$ & $\begin{array}{c}\text { Seamless } \\
\text { Integration }\end{array}$ \\
\hline [63] & & & $x$ & & $x$ & & & $x$ & \\
\hline [61] & $x$ & & & & $x$ & & & & $x$ \\
\hline [84] & & & $x$ & & & & $x$ & & \\
\hline [12] & & $x$ & $x$ & & & & & & \\
\hline [2] & & & $x$ & $x$ & & $x$ & & & \\
\hline [46] & $x$ & & & & $x$ & $x$ & & $x$ & \\
\hline [85] & & $x$ & $x$ & & $x$ & & & & $x$ \\
\hline [68] & & & & $x$ & & & $x$ & & $x$ \\
\hline [74] & & & $x$ & & $x$ & & $x$ & & \\
\hline [67] & & & & & & & & $x$ & $x$ \\
\hline [75] & & & $x$ & & & & $x$ & & $x$ \\
\hline
\end{tabular}

\subsection{Traditional vs Smart Factory}

IoT implementation in manufacturing processes has set a deviation from a centralised factory structure to a decentralised system $[18,69]$. This technology allows industries and machines to use self-optimisation and reconfiguration abilities to acclimatise their behaviour to alterations in missions and operative conditions $[15,77]$. The ability to collect valuable data is the core of smart factories [61,78]. Motors, robotics and intelligent sensors are included in this technology which is engaged in the assembly lines and production of the manufacturing industry $[61,86]$.

The smart factory upsurges to an interconnected and resilient system from classic automation and institutes a persistent data stream from linked production systems and operations to learn and acclimatise to changing demands [1,44,87]. Data from human, physical and operational assets are assimilated to drive maintenance, digitisation of operations, manufacturing, inventory tracking and other activities in manufacturing systems [17,88,89]. The main aim of smart factories is to use appropriate engineering procedures and intelligent production systems for the prosperous and unified enactment of production facilities $[8,90,91]$. The endorsement of a smart factory can help change the intercommunication of engineered systems in the same way as the internet has changed the way people communicate with each other [66].

The extant empirical research has divided the smart factories into three components [92]. The web information is used to perform with high efficiency, agility and flexibility and use different levels of understanding to bring transparency to the factory. Firstly, real-time data and information from several components such as sensors are used by machines to achieve self-awareness and self-comparison [93,94]. This self-awareness, also known as predictive maintenance, enables the machines to evaluate their work and analyse any malfunctioning components $[78,95]$. Consequently, the machine can prevent possible failures and predict risks associated with the final product. Secondly, smart machines can examine their performance and efficiency with other machines by sharing information through cyberspace $[72,96,97]$. This self-comparison of the machine allows it to adapt its settings and efficiency according to the knowledge collected from information sharing. At this point, the manufacturing system can customise individual machines' performance based on self-comparison [34,75]. Finally, as a result, the production system can change its configurations to modify the position of all the machines involved in the manufacture of 
every single product. This guarantees good-quality products with optimum operational costs $[42,98]$. Figure 9 shows a comparison of the traditional factory and smart factory.

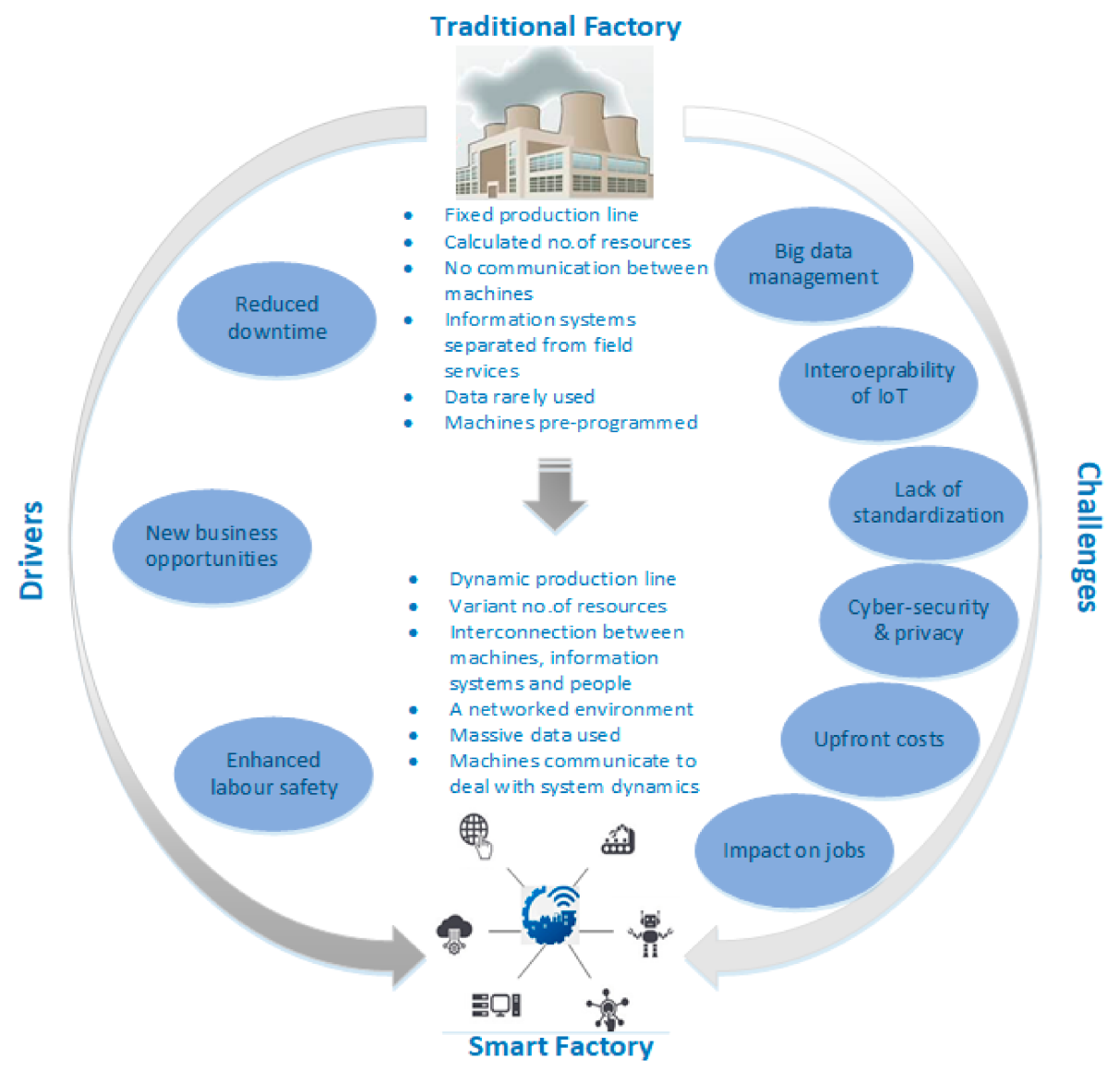

Figure 9. Comparison of traditional and smart factories.

A smart factory revolves around key features that play an essential role in enabling a more productive system, reducing assembly downtime and anticipating and adapting to changes in a broader network [1,15]. These features allow the manufacturers to have enhanced visibility throughout their assets and enable them to go through the challenges encountered by factory systems [62]. Consequently, enhanced productivity, efficiency and greater receptivity to changes in supplier and customer demands can be met easily $[1,99]$.

- Connectivity and Optimisation: The interconnected nature of a smart factory is the most crucial source of value. In a connected smart factory, assets integrated with WSNs constantly take data sets from sources, ensuring that the data reflect current conditions [66,100]. A comprehensive view of supply chain processes can be gained due to incorporating data from business systems, driving overall supply network efficiency [54,101]. Similarly, reduced manual intervention and enhanced reliability are achieved with an optimised smart factory [102]. The automated workflows improved tracking, and efficient energy results allow the smart factory to enhance yield, uptime, and quality and reduce costs and wastage [70].

- Agility and Proactivity: The agility and flexibility of a smart factory enable the organisation to readjust to schedule and product modifications with as little human intervention as possible [22,34,97].

Self-configure and self-awareness abilities are also a part of advanced smart factories. The system can identify equipment and workflow and obtain the outcome of those adjustments in real-time [15]. Agility can enhance uptime and value by reducing changeovers as a result of product changes, increasing accuracy [77]. Similarly, machines and tools are maximised by continuously running the machines until they fail [71]. 
A proactive system identifies irregularities, helps restock inventory and identifies and addresses issues in quality while monitoring safety and maintenance concerns [61]. As a result, employees and systems can predict and react before the problems occur rather than acting on them after their occurrences $[103,104]$. This proactive ability of smart factories can improve uptime, output and quality while preventing security concerns [66,88]. Figure 10 depicts an IoT-based smart factory system.

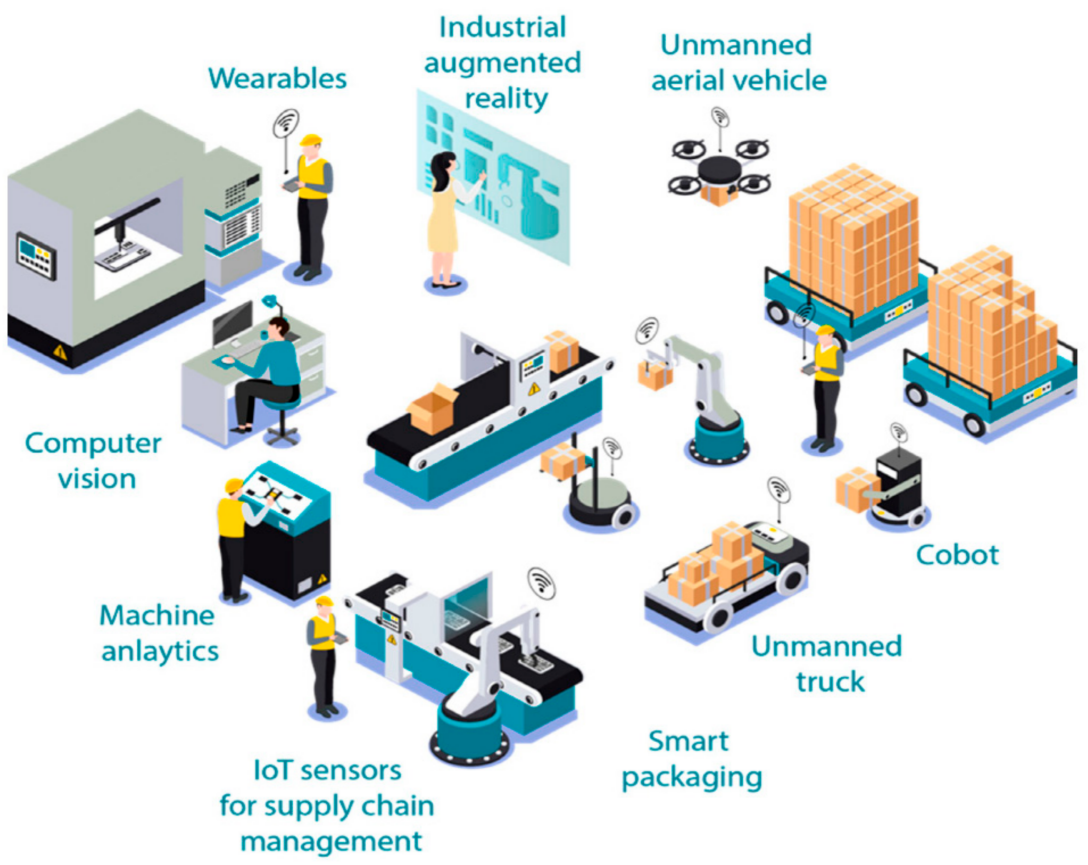

Figure 10. IoT-based smart factory (Reprinted with permission from [30]. Copyright 2020 Kalsoom et al.).

\subsection{Application of Modern Technologies}

Smart factories have successfully implemented several RFID applications, besides sensors $[46,87]$. This technology is vital to enhance several factory automation procedures ranging from automatic identification of items, instruments and other tools used in a factory to inbound/outbound management of these tools $[8,14]$. The original purpose of developing this technology was to track and identify items in retail and logistics [40,75]. However, it has been implemented for manufacturing applications, including supply chain, logistics and other commercially available systems [18,101]. In addition to RFID, cloud computing is another core technology adopted in smart factories. On-demand self-service features in cloud computing are essential for enterprises to reduce costs, provide flexibility to the system and grow in revenue and effectiveness [12,48].

The cloud bids a resilient solution for computing ability and storage that can be improved on-demand $[73,76]$. The vast amount of data generated can be transported to the cloud via cyberspace during operations, where data can be transmitted to the processes [89]. As a result, system management and optimisation, including supervision and control, can be supported by big data analytics [60,67]. The extant empirical research has reported implementing the smart factory concept in the electronics industry using three-dimensional scanners, IoT technologies, fully automated production and integrated machine control $[46,50,105]$. As a result of this implementation, the company benefitted from reduced lead time for consumers and overall expenses and improved production capacity by $25 \%$, including $50 \%$ fewer faulty products $[42,90,106]$.

The WSNs, especially sensors, allow the smart factories to observe explicit processes through the factory, increasing cognisance of what is happening at multiple levels $[5,7,49]$. For example, vibration sensors can warn when motors, bearings or other equipment must be maintained $[15,35,107]$. These warnings become alerts for preventive maintenance 
in the factories. WiMAX, Bluetooth and Wi-Fi are mobile platforms that offer low-cost, high-speed, continuous connections in smart factories [35,42].

\subsection{Drivers of IoT Implementation in the Manufacturing Industry}

- Improving Operational Efficiency and Productivity: With IoT in manufacturing, companies can use a combination of different sensors and devices such as RFID, barcoding and wireless networking to achieve enhanced visibility of various activities within the manufacturing facility $[47,86]$. This enables the manufacturing industry to achieve high operational efficiency and productivity. Similarly, improved worker safety and better workforce management are accomplished through more connected managers who are always knowledgeable about the factory's needs [54]. Paired with a wearable device, IoT technology can increase the safety of the workers by sharing urgent information and monitoring risky activities that might lead to injuries or machine malfunctions [61,91]. Further, IoT infrastructure is assembled upon interconnections amongst sensor devices and network platforms. Periodic requests between IoT devices continuously rise with IoT roles' evolution from simple sensing and transmitting tools to sensing, gathering, processing and service roles $[24,96]$. These requests will not be sent on time if the IoT devices cannot receive highly delayed requests. Due to the seemingly endless variety of IoT devices, organisations use multiple connectivity solutions that enable them to work seamlessly [67].

- Asset Utilisation and Reduced Downtime: Unplanned downtime results in high costs and is time-consuming [15,92]. Asset maintenance and alert driven systems allow the companies to receive early notifications of potential machine problems that would require repair or replacement [101]. This helps companies react in time to prevent malfunctions, improve asset utilisation and reduce costly downtime caused by equipment failures $[36,99]$. Similarly, the rapid expansion of manufacturing and information technologies has led to a change in the environment of the manufacturing industry, such as the diversity of customer demands and increasing competition in the global market [56]. Thus, companies are adopting IoT into their manufacturing systems to gain a strategic advantage $[1,18,86]$.

- Business Process Development and New Business Opportunities: IoT brings many possibilities to modern manufacturing industries in gaining efficient system performances in globalised and distributed environments [88,108]. Companies are successfully adopting wireless sensor and actuator networks (WSANs) due to their ability to deliver flexible monitoring and control of industrial processes [24,48]. Consequently, helping to achieve more complicated tasks and carry out self-configuration and selforganisation mechanisms improves business processes [109]. Similarly, organisations are now investing more in adopting IoT technologies and enhancing efficiency by reducing costs [108]. Ease of access to different data resources online enables firms to reduce their costs and expenses [1]. Moreover, predictive maintenance helps businesses reduce failure costs and expenses, thus reducing overall operational costs [42,81].

\subsection{Challenges in Manufacturing Industry 4.0}

- Lack of Talent and Strategy: With the physical world being digitised at an alarming pace, an explosion of smart devices has been seen in recent years; these devices are in continuous communication with one another, creating vast amounts of data $[72,73,110]$. Smart software and hardware are essential for a smart factory to perform operational tasks in a very complex manufacturing environment continuously. Nonetheless, some latent technical and nontechnical issues such as talent shortage, lack of software and hardware training, crisis management and risk management need to be addressed [88].

- Intelligent Decision Making and Negotiation Mechanism: Smart machines are vital parts of a smart factory $[54,57]$. With advanced IoT technologies, smart machines should have the ability to be autonomous [39]. This implies that the smart machines should have the capability to decide by themselves instead of depending on the in- 
structions provided by humans and confer with each other and smart products [14,73]. This shows that the autonomous abilities of the machines are vital for self-organised manufacturing systems [62]. The majority of the researchers agree that additional exploration is still needed in this domain to achieve an autonomous manufacturing system rather than a hierarchical system $[26,63,80,87]$.

- System Modelling and Analysis: For a mechanical system, self-awareness of the machine is its ability to assess its condition and react to the assessment output [41]. The real-time machine condition can be shown to the machine controller and manager for adaptive control and in-time maintenance, respectively [8]. However, in manufacturing systems, where a fleet of machines is involved, self-awareness and selforganisation are still far from being realised $[3,36]$. The smart factory system adopts the self-organisation theory, and the self-organised process may direct unanticipated situations leading to chaos. Therefore, more adaptive and flexible approaches are needed to adopt these systems fully [62].

- Big Data Management: Big data and data analytics illustrate data sets and analytical tools in the extant empirical research. These massive and complex tools need advanced data storage, management, analysis and visualisation technologies [81,111]. Cloud computing helps successfully utilise big data and provides a scalable computing ability to the manufacturing systems $[22,33,85]$. However, the core challenge in handling a massive volume of data in this digital age is marked by the unstable external environment $[73,81]$. A multifaceted environment characterises manufacturing industries; a fault in one of the machines, for a few seconds, might lead to substantial system disruptions and operative costs $[67,97]$. Therefore, it is imperative to focus on the practical implications of data that divulge the value and performance-related aspects instead of gathering different data followed by the struggle to manage it $[86,102]$. Organisations should be prepared to deal with data challenges that involve privacy, effective data mining, storage management and availability [112].

- Cybersecurity: Cybersecurity risks become pertinent when vast amounts of smart resources are networked together to accumulate data on the cloud [23,72,110,113]. Threats that might affect personal devices and complex IT systems arise from these cyber risks, making individuals and organisations susceptible to fiscal and operational harms $[14,114]$. Likewise, a data breach in which data are extracted from the system can be as harmful as insufficient data collection from the smart system [33]. Hence, protection is needed for systems and communications, as many systems communicate over massive distances, making them susceptible to security ruptures [99]. Smart grids are one of the leading examples of the leading edge of IoT in industrial systems [34].

- Impact on Jobs: Continuous evolution of smart factories is changing the role of employees from what they do in traditional factories. Automation will take up the repeated, mundane tasks or impact the labour shortage and the people in these factories [42]. Similarly, special skills and acquaintance will be obligatory [21,115]. For instance, IT managers who have no expertise working in a smart manufacturing environment face difficulties meeting targets, and an ageing workforce will impact many industries in the future [24]. The empirical research also anticipated an immense skill gap created with experienced and skilled workers [41,57]. Thus, it is critically important to capture the knowledge accumulated from the senior employees, disseminate it and make it accessible to the new workforce before retirement [36].

- Interoperability and Standardisation of IoT: A potential value of approximately $40 \%$ is developed by IoT, as interoperability of IoT has a crucial task in different settings $[68,116]$. A technical challenge, in the form of developing the ability to communicate with each other, is persistent where numerous devices of diverse kinds and technical profiles (e.g., autonomous drones and vehicles), produced by a variety of multiple brands (each with their standards), will function [22,25]. There are several IoT standards, but there is a lack of internationally acceptable standardisation, resulting in complications and confusion for the professionals when adopting IoT [117]. Inadequate access to 
real-time value data from IoT for individuals and organisations will be a technical challenge [89]. For instance, information cannot be exchanged between two IoT devices because of their languages [88].

- Significant Upfront Costs: Cost is an essential factor in determining the feasibility of developing IoT solutions in a business. The manufacturing industry is exceedingly cost-sensitive; the major contributing factor is the identified need for the machines to create more usable data for manufacturing operational professionals $[53,69]$. Therefore, manufacturers need to find creative solutions to capture operational data [5]. Manufacturers cannot replace machines with new ones in such a scenario, as this would cost hundreds to thousands of dollars. The high costs of implementing IoT technologies add to the burden for manufacturers, thus leading to slow adoption of these technologies in some sectors $[14,69]$. The empirical research also reported costs such as workforce training and development, systems integrations, security and opportunity costs of the learning curve [118,119].

- Sustainability and Energy Consumption: IoT is the complex network of physical devices embedded with sensors and actuators. These sensors enable everything to connect and exchange data. These devices require power and energy to perform sensing, processing, communication and monitoring tasks in IoT applications [36]. However, the communication between devices for data transmission tasks remains the most energy-consuming [66]. Therefore, it is critical to keep energy costs under control, such as by reducing the power consumption of the radios when creating a connected product.

- Similarly, portable and autonomous devices will be battery-powered or energy harvesting [12,109]. Digital technologies are using low-power devices and are becoming more energy-efficient; however, the number of connected devices is increasing continuously. Moreover, the proliferation of connected devices increases network traffic, consequently increasing the energy costs of additional network equipment needed to support this traffic upsurge [73,108].

- The Intention of Humans to Adopt IoT: Regardless of unpredictable situations, trust is crucial in convincing people to embrace modern technology $[99,120]$. Trust helps users recognise the technology's social surroundings in uncertain situations, decreasing vulnerability [103]. As confidence can deal with the uncertainty and risk of the vulnerability of IoT systems, it is considered crucial for user adoption [120]. This enables the users to interact with interconnected IoT devices and systems securely, reliably and spontaneously [77]. Studies have shown that trust enhances the behavioural intent of individuals to embrace IoT products and services. In contrast, lack of trust may prove to be an obstacle in spreading IoT among individuals [33,76,107,115].

\section{Conclusions and Future Research Directions}

This study analysed and summarised IoT's applications, benefits and challenges in manufacturing I4.0 by adopting the SLR approach. It has been revealed that software development, employee performance, analytical skills and software development are established due to monitoring and better communications. IoT is considered an enhancement of the internet, but it lacks global coherence even though a well-documented design resides within the internet. As a result, data security and privacy issues arise, resulting in implicit assumptions related to sharing data among sectors, applications and things. In Industry 4.0, automated manufacturing systems and remotely monitored control operations are helping the manufacturing industry to gain operational efficiency by reducing task errors $[15,42]$. Therefore, customers can achieve enhanced satisfaction and experience through customer care integration and demand with actual product performance and usage [11,81]. IoT offers various methods by which more compelling customer experiences across digital and physical worlds $[18,74,75]$. Recently, academia has found particular interest in IoT implications; therefore, an expansion in the body of literature can be found in this domain. 
In this research, the applications and uses of IoT-based technologies, widely accepted in the manufacturing industry, have been discussed. However, as an emerging technology, it has yet to overcome both technical and nontechnical challenges in its full adoption by various communities and businesses $[3,33,41,76]$. Improving operational efficiency and productivity, asset utilisation and reduced downtime, business process development, and new business opportunities are the drivers of IoT implementation in Industry 4.0. The technical challenges include system modelling and analysis, big data management, cyber-security, interoperability and standardisation of IoT and sustainability and energy consumption. In contrast, nontechnical challenges include lack of talent and strategy, intelligent decision making and negotiation mechanism, impact on jobs, significant upfront costs and impact of human behavioural intentions on IoT adoption (Sections 3.4 and 3.5). The impact of IoT on society cannot be discussed without focusing on the uses of these devices [33,41,66,121]; a comprehensive study has been conducted on the uses and applications of these devices and their challenges risks for businesses. Though IoT is one of the central pillars of Industry 4.0, it poses several challenges, including technological challenges for its implementation, effective and efficient utilisation and management $[16,17,47,76,105]$. The extant empirical research indicates that IoT has been successfully implemented in operations and maintenance, service management and production asset management $[14,26,62]$. These areas use appropriate engineering techniques and intelligent manufacturing systems to integrate production facilities [87] successfully. In a smart factory environment, the manufacturer can satisfy customer requests by altering the manufacturing specifications and other machine settings at the last moment $[18,45,80]$. Therefore, the competency to readapt and evolve along with the emergent requirements of the organisation is the main driver behind adopting IoT in industries $[1,50,64,72,122]$.

Current performance measurement systems have influenced peoples' organisational capabilities, behaviour and performance outcomes $[4,76]$. The rapid development of IoT technology creates a visualisation of IoT in which the forthcoming generation will work with highly interacting humans, societies and smart factories. This will give rise to a phenomenon called opportunistic IoT [24,39], which addresses the link created between different societies (by connecting devices) formed by the opportunistic interactive human nature and, hence, concentrates on the human side of IoT $[4,67]$. Moreover, ethical issues related to the rights to private life, secure data and information sharing also arise [33,34]. These matters need to be considered for future research. In addition, due to several challenges the industry faces (as identified in this research), all the promised benefits of I4.0 have not been realised; addressing these challenges will be the key to success and competitiveness in the industry in the future. With the arrival of Industry 5.0, future research needs to look into the depths of this new era of digitalisation. Table 4 summarises the identified research gaps.

Table 4. Conclusions and future research directions.

\begin{tabular}{|c|c|c|}
\hline $\begin{array}{c}\text { Extant Empirical Research Themes } \\
\text { and Key Sources }\end{array}$ & Current Research Gaps & $\begin{array}{c}\text { Future Research } \\
\text { Questions/Directions }\end{array}$ \\
\hline $\begin{array}{l}\text { Intelligent decision making and } \\
\text { negotiation mechanism for the } \\
\text { application of IoT in manufacturing } \\
\text { Industry } 4.0[9,11,26,85,106]\end{array}$ & $\begin{array}{l}\text { Current studies have identified that the } \\
\text { autonomous abilities of smart machines are vital } \\
\text { for self-organised manufacturing systems in } \\
\text { smart factories. However, research on how to } \\
\text { achieve an autonomous manufacturing system } \\
\text { rather than a hierarchical system is unknown. }\end{array}$ & $\begin{array}{l}\text { How can smart factories achieve } \\
\text { autonomous manufacturing systems } \\
\text { rather than hierarchical systems? }\end{array}$ \\
\hline $\begin{array}{c}\text { Big data management in the context } \\
\text { of manufacturing Industry } 4.0 \text { from } \\
\text { IoT application perspective } \\
{[13,48,90,123]}\end{array}$ & $\begin{array}{l}\text { The extant empirical research has shown that } \\
\text { vast amounts of complex data are generated by } \\
\text { Industry 4.0, which requires advanced data } \\
\text { storage, management, analysis and visualisation } \\
\text { technologies. Although cloud computing helps } \\
\text { utilise big data, managing such data by focusing } \\
\text { on practical implications has been a } \\
\text { struggle for organisations. }\end{array}$ & $\begin{array}{l}\text { How can organisations use data } \\
\text { mining techniques to manage big } \\
\text { data effectively? }\end{array}$ \\
\hline
\end{tabular}


Table 4. Cont.

\begin{tabular}{ccc}
$\begin{array}{c}\text { Extant Empirical Research Themes } \\
\text { and Key Sources }\end{array}$ & Current Research Gaps & $\begin{array}{c}\text { Future Research } \\
\text { Questions/Directions }\end{array}$ \\
\hline
\end{tabular}

Cybersecurity issues for the application of IoT in manufacturing Industry $4.0[15,34,57,91,110,124]$

Impact on jobs and knowledge management due to application of IoT in the manufacturing Industry 4.0 $[16,36,41,118,125]$
Many devices are connected and exposed to cybersecurity risks in Industry 4.0; data breaches may lead to organisations becoming vulnerable to financial and operational damages. Although much research has been conducted in this domain, approaches to prevent cyber risks in smart grids are unknown.
How can smart grids be made secure to prevent cyber risks?
With machines taking up most of the tasks in a smart factory, employees will take on more complex roles in these factories. This will need special skills and knowledge to fill these job roles, creating a vast skill gap with retiring experienced and skilled workers. Little is known about what skill gaps will be created and how knowledge can be captured from senior employees or management.

The existing literature shows the importance of interoperability of devices connected in Industry 4.0 and highlights the lack of standardisation.

However, approaches to achieve the standardisation of IoT devices is unknown.

Studies have shown that smart factories are cost-sensitive and high costs of IoT deployment lead to slow adoption of this technology in some sectors. These studies have highlighted different costs without providing creative solutions to help capture data from machines to prevent help capture data from machines
unplanned downtime.
How can skill gaps be filled for the complex roles in smart factories?
IoT implementation costs in the manufacturing Industry 4.0 $[14,91,126]$
The increased number of connected devices around the globe are leading to energy consumption and carbon emissions. Current Sustainability and energy consumption $[36,66,127]$

The impact of human behavioural intentions on the adoption of IoT $[17,33,76,107,128]$ research lacks information on how smart factories, where many autonomous machines are used, can reduce power consumption and energy costs.
What steps should be taken to enable effective interoperability and standardisation of IoT devices in Industry 4.0 ?

What creative and cost-effective solutions can organisations adopt to help capture data from machines to prevent unplanned downtime?
In IoT, the trust could be considered crucial for user adoption as it can deal with uncertainty and risk of vulnerability from interconnected devices. However, studies on technical aspects of IoT in the manufacturing industry are more widespread than those on the behavioural and attitudinal characteristics. There is a lack of effective trust models to guide IoT designers and service providers to understand and manage the requirements of IoT users in the current literature.
How can smart factories optimise the use of power and energy by autonomous machines?
How can existing trust models guide IoT designers and providers to understand and manage the requirements of IoT users?
Most of the extant empirical research on the application, drivers and barriers of IoT in manufacturing Industry 4.0 is carried out in developed and/or technologically advanced countries. However, to what extent IoT is being adopted and implemented in developing and technologically least developed countries is unknown, including applications, drivers and barriers.

What is the impact of IoT in the manufacturing industries of developing and least technologically advanced countries? 
Author Contributions: Conceptualisation, T.K., S.A. and Z.P.; methodology, T.K., S.A., P.M.R.-u.-S. and M.A.; formal analysis, T.K., S.A., M.A. and P.A.; investigation, T.K. and S.A.; resources, Z.P., M.A.I. and M.U.-R.; data curation, T.K.; writing—original draft preparation, T.K., S.A., P.M.R.-u.-S., M.A. and P.A.; writing-review and editing, T.K., Z.P., M.A.I. and M.U.-R.; visualisation, T.K. and S.A.; supervision, Z.P. and S.A.; funding acquisition, M.A.I. and M.U.-R., project administration, S.A. and Z.P. All authors have read and agreed to the published version of the manuscript.

Funding: This research received no external funding.

Institutional Review Board Statement: Not applicable.

Informed Consent Statement: Not applicable.

Conflicts of Interest: The authors declare no conflict of interest.

\section{References}

1. Agrifoglio, R.; Cannavale, C.; Laurenza, E.; Metallo, C. How emerging digital technologies affect operations management through co-creation. Empirical evidence from the maritime industry. Prod. Plan. Control 2017, 28, 1298-1306. [CrossRef]

2. Brozzi, R.; Forti, D.; Rauch, E.; Matt, D.T. The Advantages of Industry 4.0 Applications for Sustainability: Results from a Sample of Manufacturing Companies. Sustainability 2020, 12, 3647. [CrossRef]

3. Ghobakhloo, M. The future of manufacturing industry: A strategic roadmap toward Industry 4.0. J. Manuf. Technol. Manag. 2018, 29, 910-936. [CrossRef]

4. Feng, Q.; Shanthikumar, J.G. How Research in production and operations management may evolve in the era of big data. Prod. Oper. Manag. 2017, 27, 1670-1684. [CrossRef]

5. Bortolini, M.; Galizia, F.G.; Mora, C. Reconfigurable manufacturing systems: Literature review and research trend. J. Manuf. Syst. 2018, 49, 93-106. [CrossRef]

6. Vuksanović Herceg, I.; Kuč, V.; Mijušković, V.M.; Herceg, T. Challenges and driving forces for Industry 4.0 implementation. Sustainability 2020, 12, 4208. [CrossRef]

7. Tortorella, G.L.; Giglio, R.; van Dun, D. Industry 4.0 adoption as a moderator of the impact of lean production practices on operational performance improvement. Int. J. Oper. Prod. Manag. 2019, 39, 860-886. [CrossRef]

8. Kamble, S.S.; Gunasekaran, A.; Sharma, R. Analysis of the driving and dependence power of barriers to adopt Industry 4.0 in Indian manufacturing industry. Comput. Ind. 2018, 101, 107-119. [CrossRef]

9. Resta, B.; Gaiardelli, P.; Cavalieri, S.; Dotti, S. The servitisation of manufacturing. Int. J. Oper. Prod. Manag. 2014, 9, 302-314.

10. Drath, R.; Horch, A. Industrie 4.0: Hit or hype? [Industry Forum]. IEEE Ind. Electron. Mag. 2014, 8, 56-58. [CrossRef]

11. Zhang, Y.; Zhao, L.; Qian, C. Modeling of an IoT-enabled supply chain for perishable food with two-echelon supply hubs. Ind. Manag. Data Syst. 2017, 117, 1890-1905. [CrossRef]

12. Bibby, L.; Dehe, B. Defining and assessing Industry 4.0 maturity levels-case of the defence sector. Prod. Plan. Control 2018, 29, 1030-1043. [CrossRef]

13. Ehie, I.C.; Chilton, M.A. Understanding the influence of IT/OT Convergence on the adoption of Internet of Things (IoT) in manufacturing organisations: An empirical investigation. Comput. Ind. 2020, 115, 103166. [CrossRef]

14. Gottge, S.; Menzel, T.; Forslund, H. Industry 4.0 technologies in the purchasing process. Ind. Manag. Data Syst. 2020, 120, 730-748. [CrossRef]

15. Ulieru, M.; Cobzaru, M. Building holonic supply chain management systems: An e-logistics application for the telephone manufacturing industry. IEEE Trans. Ind. Inform. 2005, 1, 18-30. [CrossRef]

16. Ivanov, D.; Dolgui, A.; Sokolov, B.; Werner, F.; Ivanova, M. A dynamic model and an algorithm for short-term supply chain scheduling in the smart factory industry 4.0. Int. J. Prod. Res. 2015, 54, 386-402. [CrossRef]

17. Liao, Y.; Deschamps, F.; Loures, E.D.F.R.; Ramos, L.F.P. Past, present and future of Industry 4.0-A systematic literature review and research agenda proposal. Int. J. Prod. Res. 2017, 12, 3609-3629. [CrossRef]

18. Lu, Y. Industry 4.0: A survey on technologies, applications and open research issues. J. Ind. Inf. Integr. 2017, 6, 1-10. [CrossRef]

19. Tuttokmagi, O.; Kaygusuz, A. Smart Grids and Industry 4.0. In Proceedings of the 2018 International Conference on Artificial Intelligence and Data Processing (IDAP), Malatya, Turkey, 28-30 September 2018; pp. 1-6. [CrossRef]

20. Gokalp, M.O.; Kayabay, K.; Akyol, M.A.; Eren, P.E.; Koçyiğit, A. Big data for Industry 4.0: A conceptual framework. In Proceedings of the 2016 International Conference on Computational Science and Computational Intelligence, CSCI, Las Vegas, NV, USA, 15-17 December 2016; pp. 431-434.

21. Benitez, G.; Ayala, N.F.; Frank, A.G. Industry 4.0 innovation ecosystems: An evolutionary perspective on value cocreation. Int. J. Prod. Econ. 2020, 228, 107735. [CrossRef]

22. Lass, S.; Gronau, N. A factory operating system for extending existing factories to Industry 4.0. Comput. Ind. 2019, 115, 103128. [CrossRef]

23. Yen, C.-T.; Liu, Y.-C.; Lin, C.-C.; Kao, C.-C.; Wang, W.-B.; Hsu, Y.-R. Advanced manufacturing solution to industry 4.0 trend through sensing network and Cloud Computing technologies. In Proceedings of the 2014 IEEE International Conference on Automation Science and Engineering (CASE), New Taipei, Taiwan, 18-22 August 2014; pp. 1150-1152. [CrossRef] 
24. De Falco, S.E.; Renzi, A.; Orlando, B.; Cucari, N. Open collaborative innovation and digital platforms. Prod. Plan. Control. 2017, 28, 1344-1353. [CrossRef]

25. Figay, N.; Ghodous, P.; Khalfallah, M.; Barhamgi, M. Interoperability framework for dynamic manufacturing networks. Comput. Ind. 2012, 63, 749-755. [CrossRef]

26. Perera, C.; Liu, C.H.; Jayawardena, S.; Chen, M. A Survey on Internet of Things from Industrial Market Perspective. IEEE Access 2014, 2, 1660-1679. [CrossRef]

27. Jeon, B.; Yoon, J.S.; Um, J.; Suh, S.H. The architecture development of Industry 4.0. compliant smart machine tool system (SMTS). J. Intell. Manuf. 2020, 31, 1837-1859. [CrossRef]

28. Denyer, D.; Tranfield, D. Producing a systematic review. The Sage Handbook of Organizational Research Methods. Review. In The Sage Handbook of Organisational Research Methods; Buchanan, D., Bryam, A., Eds.; Sage: Thousand Oaks, CA, USA, 2009.

29. Manavalan, E.; Jayakrishna, K. A review of Internet of Things (IoT) embedded sustainable supply chain for industry 4.0 requirements. Comput. Ind. Eng. 2018, 127, 925-953. [CrossRef]

30. Kalsoom, T.; Ramzan, N.; Ahmed, S. Societal Impact of IoT-Lead Smart Factory in the Context of Industry 4.0. In Proceedings of the 2020 International Conference on UK-China Emerging Technologies, UCET, Glasgow, UK, 20-21 August 2020.

31. Cao, Q.; Schniederjans, D.G.; Schniederjans, M. Establishing the use of cloud computing in supply chain management. Oper. Manag. Res. 2017, 10, 47-63. [CrossRef]

32. Chauhan, C.; Singh, A. A review of Industry 4.0 in supply chain management studies. J. Manuf. Technol. Manag. 2019, 31, 863-886. [CrossRef]

33. Rojko, A. Industry 4.0 Concept: Background and Overview. Int. J. Interact. Mob. Technol. (iJIM) 2017, 11, 77-90. [CrossRef]

34. Rymaszewska, A.; Helo, P.; Gunasekaran, A. IoT powered servitisation of manufacturing-An exploratory case study. Int. J. Prod. Econ. 2017, 192, 92-105. [CrossRef]

35. Derigent, W.; Cardin, O.; Trentesaux, D. Industry 4.0: Contributions of holonic manufacturing control architectures and future challenges. J. Intell. Manuf. 2020, 32, 1797-1818. [CrossRef]

36. Kong, X.T.R.; Luo, H.; Huang, G.Q.; Yang, X. Industrial wearable system: The human-centric empowering technology in Industry 4.0. J. Intell. Manuf. 2018, 30, 2853-2869. [CrossRef]

37. Tranfield, D.; Denyer, D.; Smart, P. Towards a Methodology for Developing Evidence-Informed Management Knowledge by Means of Systematic Review Introduction: The need for an evidence-informed approach. Br. J. Manag. 2003, 14, 207-222. [CrossRef]

38. Kim, G.; Kim, J.; Lee, S.; Gijeong, K.; JunHo, K.; Sungwon, L. An SDN based fully distributed NAT traversal scheme for IoT global connectivity. In Proceedings of the 2015 International Conference on Information and Communication Technology Convergence (ICTC), Jeju Island, Korea, 28-30 October 2015; pp. 807-809. [CrossRef]

39. Afzal, B.; Umair, M.; Shah, G.A.; Ahmed, E. Enabling IoT platforms for social IoT applications: Vision, feature mapping, and challenges. Futur. Gener. Comput. Syst. 2019, 92, 718-731. [CrossRef]

40. Castelo-Branco, I.; Cruz-Jesus, F.; Oliveira, T. Assessing Industry 4.0 readiness in manufacturing: Evidence for the European Union. Comput. Ind. 2019, 107, 22-32. [CrossRef]

41. Khaleel, H.; Conzon, D.; Kasinathan, P.; Brizzi, P.; Pastrone, C.; Pramudianto, F.; Eisenhauer, M.; Cultrona, P.A.; Rusina, F.; Lukac, G.; et al. Heterogeneous applications, tools, and methodologies in the car manufacturing industry through an IoT approach. IEEE Syst. J. 2015, 11, 1412-1423. [CrossRef]

42. Kharlamov, A.; Parry, G. Advanced supply chains: Visibility, blockchain and human behaviour. Contrib. Manag. Sci. 2018, 321-343. [CrossRef]

43. Kalsoom, T.; Ramzan, N.; Ahmed, S.; Ur-Rehman, M. Advances in Sensor Technologies in the Era of Smart Factory and Industry 4.0. Sensors 2020, 20, 6783. [CrossRef]

44. Osterrieder, P.; Budde, L.; Friedli, T. The smart factory as a key construct of Industry 4.0: A systematic literature review. Int. J. Prod. Econ. 2020, 221, 107476. [CrossRef]

45. Ng, I.C.; Wakenshaw, S.Y. The Internet-of-Things: Review and research directions. Int. J. Res. Mark. 2017, 34, 3-21. [CrossRef]

46. Sanchez, L.M.; Nagi, R. A review of agile manufacturing systems. Int. J. Prod. Res. 2001, 39, 3561-3600. [CrossRef]

47. Sanders, A.; Elangeswaran, C.; Wulfsberg, J. Industry 4.0 implies lean manufacturing: Research activities in industry 4.0 function as enablers for lean manufacturing. J. Ind. Eng. Manag. 2016, 9, 811-833. [CrossRef]

48. Ghobakhloo, M. Corporate survival in Industry 4.0 era: The enabling role of lean-digitsed manufacturing. J. Manuf. Technol. Manag. 2020, 31, 1-30. [CrossRef]

49. Tao, F.; Zuo, Y.; Da Xu, L.; Zhang, L. IoT-Based intelligent perception and access of manufacturing resource toward cloud manufacturing. IEEE Trans. Ind. Inform. 2014, 10, 1547-1557.

50. Sony, M.; Naik, S. Key ingredients for evaluating Industry 4.0 readiness for organisations: A literature review. Benchmarking 2019. [CrossRef]

51. Maisiri, W.; van Dyk, L.; Coeztee, R. Factors that inhibit sustainable adoption of Industry 4.0 in the South African manufacturing industry. Sustainability 2021, 13, 2021. [CrossRef]

52. Balasubramanian, S.; Shukla, V.; Mangla, S.; Chanchaichujit, J. Do firm characteristics affect environmental sustainability? A literature review-based assessment. Bus. Strateg. Environ. 2021, 30, 1389-1416. [CrossRef] 
53. Lin, D.; Lee, C.; Lau, H.; Yang, Y. Strategic response to Industry 4.0: An empirical investigation on the Chinese automotive industry. Ind. Manag. Data Syst. 2018, 118, 589-605. [CrossRef]

54. Jardim-Goncalves, R.; Romero, D.; Grilo, A. Factories of the future: Challenges and leading inno-vations in intelligent manufacturing. Int. J. Comput. Integr. Manuf. 2017, 30, 4-14.

55. Fatorachian, H.; Kazemi, H. A critical investigation of Industry 4.0 in manufacturing: Theoretical operationalisation framework Prod. Plan. Control. 2018, 29, 633-644. [CrossRef]

56. Sung, T.K. Industry 4.0: A Korea perspective. Technol. Forecast. Soc. Chang. 2018, 132, 40-45. [CrossRef]

57. Nagy, J.; Oláh, J.; Erdei, E.; Máté, D.; Popp, J. The role and impact of Industry 4.0 and the internet of things on the business strategy of the value chain-the case of Hungary. Sustainability 2018, 10, 3491. [CrossRef]

58. Ahmed, S.; Kalsoom, T.; Ramzan, N.; Pervez, Z.; Azmat, M.; Zeb, B.; Rehman, M.U. Towards Supply Chain Visibility Using Internet of Things: A Dyadic Analysis Review. Sensors 2021, 21, 4158. [CrossRef] [PubMed]

59. Al-Fuqaha, A.; Guizani, M.; Mohammadi, M.; Aledhari, M.; Ayyash, M. Internet of Things: A Survey on Enabling Technologies, Protocols, and Applications. IEEE Commun. Surv. Tutor. 2015, 17, 2347-2376. [CrossRef]

60. Leyh, C.; Martin, S.; Schäffer, T. Industry 4.0 and Lean Production-A Matching Relationship? An analysis of selected Industry 4.0 models. In Proceedings of the 2017 Federated Conference on Computer Science and Information Systems, Pague, Czech Republic, 3-6 September 2017.

61. Newbert, S.L. Empirical research on the resource-based view of the firm: An assessment and suggestions for future research. Strat. Manag. J. 2007, 28, 121-146. [CrossRef]

62. Agostini, L.; Filippini, R. Organisational and managerial challenges in the path toward Industry 4.0. Eur. J. Innov. Manag. 2019, 22, 406-421. [CrossRef]

63. Lightfoot, H.; Baines, T.; Smart, P. The servitisation of manufacturing: A systematic literature review of interdependent trends. Int. J. Oper. Prod. Manag. 2013, 33, 1408-1434. [CrossRef]

64. Weking, J.; Stöcker, M.; Kowalkiewicz, M.; Böhm, M.; Krcmar, H. Leveraging Industry 4.0—A business model pattern framework. Int. J. Prod. Econ. 2019, 225, 107588. [CrossRef]

65. Nikitas, A.; Michalakopoulou, K.; Njoya, E.T.; Karampatzakis, D. Artificial Intelligence, Transport and the Smart City: Definitions and Dimensions of a New Mobility Era. Sustainability 2020, 12, 2789. [CrossRef]

66. Galati, F.; Bigliardi, B. Industry 4.0: Emerging themes and future research avenues using a text mining approach. Comput. Ind. 2019, 109, 100-113. [CrossRef]

67. Chong, S.; Pan, G.T.; Chin, J.; Show, P.L.; Yang, T.C.K.; Huang, C.M. Integration of 3D printing and Industry 4.0 into engineering teaching. Sustainability 2018, 11, 3960. [CrossRef]

68. Rafi-Ul-Shan, P.M.; Grant, D.B.; Perry, P.; Ahmed, S. Relationship between sustainability and risk management in fashion supply chains: A systematic literature review. Int. J. Retail Distrib. Manag. 2018, 46, 466-486. [CrossRef]

69. Ben-Daya, M.; Hassini, E.; Bahroun, Z. Internet of things and supply chain management: A literature review. Int. J. Prod. Res. 2017, 57, 4719-4742. [CrossRef]

70. Frank, A.G.; Dalenogare, L.S.; Ayala, N.F. Industry 4.0 technologies: Implementation patterns in manufacturing companies. Int. J. Prod. Econ. 2019, 210, 15-26. [CrossRef]

71. Raj, A.; Dwivedi, G.; Sharma, A.; de Sousa Jabbour, A.B.L.; Rajak, S. Barriers to the adoption of Industry 4.0 technologies in the manufacturing sector: An inter-country comparative perspective. Int. J. Prod. Econ. 2019, 224, 107546. [CrossRef]

72. Esmaeilian, B.; Behdad, S.; Wang, B. The evolution and future of manufacturing: A review. J. Manuf. Syst. 2016, 39, 79-100. [CrossRef]

73. Hofmann, E.; Rüsch, M. Industry 4.0 and the current status as well as future prospects on logistics. Comput. Ind. 2017, 89, 23-34. [CrossRef]

74. Morimoto, R. A socio-economic analysis of Smart Infrastructure sensor technology. Transp. Res. Part C Emerg. Technol. 2013, 31, 18-29. [CrossRef]

75. Xu, M.; Song, C.; Ji, Y.; Shih, M.-W.; Lu, K.; Zheng, C.; Duan, R.; Jang, Y.; Lee, B.; Qian, C.; et al. Toward Engineering a Secure Android Ecosystem. ACM Comput. Surv. 2016, 49, 1-47. [CrossRef]

76. Boyes, H.; Hallaq, B.; Cunningham, J.; Watson, T. The industrial internet of things (IIoT): An analysis framework. Comput. Ind. 2018, 101, 1-12. [CrossRef]

77. Birkel, H.S.; Hartmann, E. Impact of IoT challenges and risks for SCM. Supply Chain Manag. Int. J. 2019, 24, 39-61. [CrossRef]

78. Ma, H.-L.; Wang, Z.; Chan, F.T. How important are supply chain collaborative factors in supply chain finance? A view of financial service providers in China. Int. J. Prod. Econ. 2020, 219, 341-346. [CrossRef]

79. Büyüközkan, G.; Göçer, F. Digital Supply Chain: Literature review and a proposed framework for future research. Comput. Ind. 2018, 97, 157-177. [CrossRef]

80. Oztemel, E.; Gursev, S. Literature review of Industry 4.0 and related technologies. J. Intell. Manuf. 2020, 31, 127-182. [CrossRef]

81. Dalenogare, L.S.; Benitez, G.; Ayala, N.F.; Frank, A.G. The expected contribution of Industry 4.0 technologies for industrial performance. Int. J. Prod. Econ. 2018, 204, 383-394. [CrossRef]

82. Jiao, J.R.; You, X.; Kumar, A. An agent-based framework for collaborative negotiation in the global manufacturing sup-ply chain network. Robot. Comput. Integr. Manuf. 2006, 22, 239-255. [CrossRef] 
83. Thong, J.Y.; Yap, C.S.; Raman, K.S. Top Management support, external expertise and information systems implementation in small businesses. Inf. Syst. Res. 1996, 7, 248-267. [CrossRef]

84. Witsch, M.; Vogel-Heuser, B. Towards a Formal Specification Framework for Manufacturing Execution Systems. IEEE Trans. Ind. Inform. 2012, 8, 311-320. [CrossRef]

85. Kozjek, D.; Vrabič, R.; Rihtaršič, B.; Lavrač, N.; Butala, P. Advancing manufacturing systems with big-data analytics: A conceptual framework. Int. J. Comput. Integr. Manuf. 2020, 33, 169-188. [CrossRef]

86. Maganha, I.; Silva, C.; Ferreira, L.M.D. Understanding recon fi gurability of manufacturing systems: An empirical analysis. J. Manuf. Syst. 2018, 48, 120-130. [CrossRef]

87. Dallasega, P.; Rauch, E.; Linder, C. Industry 4.0 as an enabler of proximity for construction supply chains: A systematic literature review. Comput. Ind. 2018, 99, 205-225. [CrossRef]

88. Wagire, A.A.; Rathore, A.P.S.; Jain, R. Analysis and synthesis of Industry 4.0 research landscape Using latent se-mantic analysis approach. J. Manuf. Technol. Manag. 2020, 31, 31-51. [CrossRef]

89. Wan, C.; Zheng, H.; Guo, L.; Xu, X.; Zhong, R.Y.; Yan, F. Cloud manufacturing in China: A review. Int. J. Comput. Integr. Manuf. 2020, 33, 229-251. [CrossRef]

90. Ortiz, A.M.; Hussein, D.; Park, S.; Han, S.N.; Crespi, N. The Cluster Between Internet of Things and Social Networks: Review and Research Challenges. IEEE Internet Things J. 2014, 1, 206-215. [CrossRef]

91. Pacchini, A.P.T.; Lucato, W.C.; Facchini, F.; Mummolo, G. The degree of readiness for the implementation of Industry 4.0. Comput. Ind. 2019, 113, 103125. [CrossRef]

92. Müller, J.M. Business model innovation in enterprises Strategies for industry 4.0 providers and users. J. Manuf. Technol. Manag. 2019, 30, 1127-1142. [CrossRef]

93. Negri, M.; Cagno, E.; Colicchia, C.; Sarkis, J. Integrating sustainability and resilience in the supply chain: A systematic literature review and a research agenda. Bus. Strat. Environ. 2021. [CrossRef]

94. Nudurupati, S.S.; Tebboune, S.; Hardman, J. Contemporary performance measurement and management (PMM) in digital economies. Prod. Plan. Control. 2015, 27, 226-235. [CrossRef]

95. Ferrari, A.M.; Volpi, L.; Settembre-Blundo, D.; García-Muiña, F.E. Dynamic life cycle assessment (LCA) integrating life cycle inventory (LCI) and Enterprise resource planning (ERP) in an industry 4.0 environment. J. Clean. Prod. 2020, 286, 125314. [CrossRef]

96. Bi, Z.; Lin, Y.; Zhang, W. The general architecture of adaptive robotic systems for manufacturing applications. Robot. Comput. Manuf. 2010, 26, 461-470. [CrossRef]

97. Agarwal, A.; Shankar, R.; Tiwari, M. Modeling the metrics of lean, agile and leagile supply chain: An ANP-based approach. Eur. J. Oper. Res. 2006, 173, 211-225. [CrossRef]

98. Chiarini, A. Industry 4.0 technologies in the manufacturing sector: Are we sure they are all relevant for environmental performance? Bus. Strat. Environ. 2021. [CrossRef]

99. Bassi, L. Industry 4.0: Hope, hype or revolution? In Proceedings of the 2017 IEEE 3rd International Forum on Research and Technologies for Society and Industry (RTSI), Modena, Italy, 11-13 September 2017.

100. Shah, S.; Mokakangwe, K.; Bose, K.; Menon, S. The Growing Adoption of Internet of Things on Supply Chains. Procedia Manuf. 2019, 53, 108-112.

101. Haddud, A.; DeSouza, A.; Khare, A.; Lee, H. Examining potential benefits and challenges associated with the Internet of Things integration in supply chains. J. Manuf. Technol. Manag. 2017, 28, 1055-1085. [CrossRef]

102. Garrido-Hidalgo, C.; Olivares, T.; Ramirez, F.J.; Roda-Sanchez, L. An end-to-end Internet of Things solution for Re-verse Supply Chain Management in Industry 4.0. Comput. Ind. 2019, 112, 103127. [CrossRef]

103. Huang, B.; Li, C.; Yin, C.; Zhao, X. Cloud manufacturing service platform for small- and medium-sized enterprises. Int. J. Adv. Manuf. Technol. 2012, 65, 1261-1272. [CrossRef]

104. Tao, F.; Qi, Q.; Liu, A.; Kusiak, A. Data-driven smart manufacturing. J. Manuf. Syst. 2018, 48, 157-169. [CrossRef]

105. Chen, L.; Thombre, S.; Järvinen, K.; Lohan, E.S.; Alén-Savikko, A.; Leppäkoski, H.; Bhuiyan, M.Z.H.; Bu-Pasha, S.; Ferrara, G.N.; Honkala, S.; et al. Robustness, Security and Privacy in Location-Based Services for Future IoT: A Survey. IEEE Access 2017, 5, 8956-8977. [CrossRef]

106. Fan, H.; Cheng, T.C.E.; Li, G.; Lee, P.K.C. The Effectiveness of Supply Chain Risk Information Processing Capability: An Information Processing Perspective. IEEE Trans. Eng. Manag. 2016, 63, 414-425. [CrossRef]

107. Barton, D.; Court, D. Making advanced analytics work for you. Harv. Bus. Rev. 2012, 90, $78-83$.

108. Fisher, M.; Raman, A. Using Data and Big Data in Retailing. Prod. Oper. Manag. 2018, 27, 1665-1669. [CrossRef]

109. Qi, W.; Shen, Z.-J.M. A Smart-City Scope of Operations Management. Prod. Oper. Manag. 2018, 28, 393-406. [CrossRef]

110. Wang, S.; Wan, J.; Li, D.; Zhang, C. Implementing Smart Factory of Industrie 4.0: An Outlook. Int. J. Distrib. Sens. Netw. 2016, 12, 3159805. [CrossRef]

111. Wu, Q.; Zhu, Q.; Zhou, M. A correlation-driven optimal service selection approach for virtual enterprise establishment. J. Intell. Manuf. 2013, 25, 1441-1453. [CrossRef]

112. Mastos, T.D.; Nizamis, A.; Vafeiadis, T.; Alexopoulos, N.; Ntinas, C.; Gkortzis, D.; Papadopoulos, A.; Ioannidis, D.; Tzovaras, D. Industry 4.0 sustainable supply chains: An application of an IoT enabled scrap metal management solution. J. Clean. Prod. 2020, 269, 122377. [CrossRef] 
113. Tuptuk, N.; Hailes, S. Security of smart manufacturing systems. J. Manuf. Syst. 2018, 47, 93-106. [CrossRef]

114. Tu, M. An exploratory study of internet of things (IoT) adoption intention in logistics and supply chain management a mixed research approach. Int. J. Logist. Manag. 2018, 29, 131-151. [CrossRef]

115. Liu, X.; Qian, C.; Hatcher, W.G.; Xu, H.; Liao, W.; Yu, W. Secure Internet of Things (IoT)-Based Smart-World Critical Infrastructures: Survey, Case Study and Research Opportunities. IEEE Access 2019, 7, 79523-79544. [CrossRef]

116. Bi, Z.; Da Xu, L.; Wang, C. Internet of Things for Enterprise Systems of Modern Manufacturing. IEEE Trans. Ind. Inform. 2014, 10, 1537-1546. [CrossRef]

117. Chou, S.; Chen, C.W.; Kuo, Y.T. Flexibility, collaboration and relationship quality in the logistics service industry: An empirical study. Asia Pac. J. Mark. Logist. 2018, 30, 555-570. [CrossRef]

118. Atif, S.; Ahmed, S.; Wasim, M.; Zeb, B.; Pervez, Z.; Quinn, L. Towards a Conceptual Development of Industry 4.0, Servitisation, and Circular Economy: A Systematic Literature Review. Sustainability 2021, 13, 6501. [CrossRef]

119. Ellis, S.C.; Rao, S.; Raju, D.; Goldsby, T.J. RFID Tag Performance: Linking the Laboratory to the Field through Unsupervised Learning. Prod. Oper. Manag. 2018, 27, 1834-1848. [CrossRef]

120. Redelinghuys, A.J.H.; Basson, A.H.; Kruger, K. A six-layer architecture for the digital twin: A manufacturing case study implementation. J. Intell. Manuf. 2019, 32, 1383-1402. [CrossRef]

121. Frazzon, E.M.; Hartmann, J.; Makuschewitz, T.; Scholz-Reiter, B. Towards Socio-Cyber-Physical Systems in Production Networks. Procedia CIRP 2013, 7, 49-54. [CrossRef]

122. Kim, K.K.; Ryoo, S.Y.; Jung, M.D. Interorganisational information systems visibility in buyer-supplier relationships: The case of telecommunication equipment component manufacturing industry. Omega 2011, 39, 667-676. [CrossRef]

123. Wu, D.; Rosen, D.W.; Wang, L.; Schaefer, D. Cloud-based design and manufacturing: A new paradigm in digital manufacturing and design innovation. CAD Comput. Aided Des. 2015, 59, 1-14. [CrossRef]

124. Delen, D.; Hardgrave, B.C.; Sharda, R. RFID for Better Supply-Chain Management through Enhanced Information Visibility. Prod. Oper. Manag. 2009, 16, 613-624. [CrossRef]

125. Caridi, M.; Moretto, A.; Perego, A.; Tumino, A. The benefits of supply chain visibility: A value assessment model. Int. J. Prod. Econ. 2014, 151, 1-19. [CrossRef]

126. Xu, X.; He, W.; Yin, P.; Xu, X.; Wang, Y.; Zhang, H. Business network information ecological chain: A new tool for building ecological business environment in IoT era. Internet Res. 2016, 26, 446-459. [CrossRef]

127. Tibaut, A.; Rebolj, D.; Perc, M.N. Interoperability requirements for automated manufacturing systems in construction. J. Intell. Manuf. 2016, 27, 251-262. [CrossRef]

128. Huang, J.M. Laboratory Management Based on Internet of Things. Adv. Mater. Res. 2013, 711, 665-669. [CrossRef]

129. Hasegan, M.F.; Nudurupati, S.S.; Childe, S.J. Predicting performance-A dynamic capability view. Int. J. Oper. Prod. Manag. 2018, 38, 2192-2213. [CrossRef] 